\title{
IUCN
}

\section{Soil Biodiversity and Soil Organic Carbon: keeping drylands alive}

Peter Laban, Graciela Metternicht and Jonathan Davies

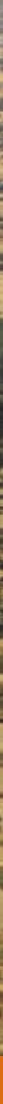

IUCN Global Drylands Initiative 


\section{About IUCN}

IUCN is a membership Union uniquely composed of both government and civil society organisations. It provides public, private and non-governmental organisations with the knowledge and tools that enable human progress, economic development and nature conservation to take place together.

Created in 1948, IUCN is now the world's largest and most diverse environmental network, harnessing the knowledge, resources and reach of more than 1,300 Member organisations and some 10,000 experts. It is a leading provider of conservation data, assessments and analysis. Its broad membership enables IUCN to fill the role of incubator and trusted repository of best practices, tools and international standards.

IUCN provides a neutral space in which diverse stakeholders including governments, NGOs, scientists, businesses, local communities, indigenous people's organisations and others can work together to forge and implement solutions to environmental challenges and achieve sustainable development.

Working with many partners and supporters, IUCN implements a large and diverse portfolio of conservation projects worldwide. Combining the latest science with the traditional knowledge of local communities, these projects work to reverse habitat loss, restore ecosystems and improve people's well-being.

www.iucn.org

https://twitter.com/IUCN/

\section{About AFD}

AFD is France's inclusive public development bank. It commits financing and technical assistance to projects that genuinely improve everyday life, both in developing and emerging countries and in the French overseas provinces. In keeping with the United Nations Sustainable Development Goals, AFD works in many sectors - energy, healthcare, biodiversity, water, digital technology, professional training, among others - to assist with transitions towards a safer, more equitable, and more sustainable world : a world in common. Through its network of 85 field offices, AFD currently finances, monitors, and assists more than 2,500 development projects in 108 countries. In 2016, AFD earmarked EUR 9.4bn to finance projects in developing countries and for overseas France. 


\section{Soil Biodiversity and Soil Organic Carbon: keeping drylands alive}

Peter Labanª, Graciela Metternichta,b and Jonathan Davies ${ }^{c}$

a'Dryland Ecosystem Specialist Group, IUCN Commission on Ecosystem Management

${ }^{b}$ School of Biological, Earth and Environmental Sciences, PANGEA Research Centre, University of New South Wales, Sydney, Australia

${ }^{\circ}$ IUCN, International Union for Conservation of Nature 
The designation of geographical entities in this book, and the presentation of the material, do not imply the expression of any opinion whatsoever on the part of IUCN concerning the legal status of any country, territory, or area, or of its authorities, or concerning the delimitation of its frontiers or boundaries.

The views expressed in this publication do not necessarily reflect those of IUCN.

This publication has been made possible in part by funding from the Agence Française de Développement.

Published by: $\quad$ IUCN, Gland, Switzerland

Copyright: $\quad$ C 2018 IUCN, International Union for Conservation of Nature and Natural Resources

Reproduction of this publication for educational or other non-commercial purposes is authorised without prior written permission from the copyright holder provided the source is fully acknowledged.

Reproduction of this publication for resale or other commercial purposes is prohibited without prior written permission of the copyright holder.

Citation: $\quad$ Peter Laban, Graciela Metternicht, and Jonathan Davies, 2018. Soil Biodiversity and Soil Organic Carbon: keeping drylands alive. Gland, Switzerland: IUCN. viii $+24 p$

ISBN:

978-2-8317-1892-7 (Print Version)

978-2-8317-1889-7 (PDF)

DOI:

https://doi.org/10.2305/IUCN.CH.2018.03.en

Cover photo: $\quad$ Tigray. $\quad$ C Dr Jonathan Davies, IUCN

Layout by: $\quad$ Gordon Arara (IUCN Publications Unit, Nairobi)

Printed by: $\quad$ KULGRAPHICS LTD, Nairobi, Kenya.

Available from: $\quad$ IUCN (International Union

for Conservation of Nature)

Global Drylands Programme

Rue Mauverney 28

1196 Gland

Switzerland

Tel +41229990000

Fax +41229990002

www.iucn.org/resources/publications

The text of this book is printed on Avalon Matt Art $133 \mathrm{gsm}$. 


\section{Table of Contents}

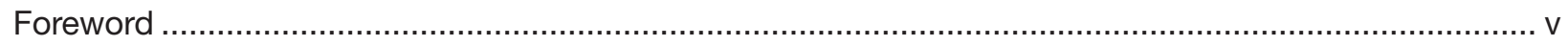

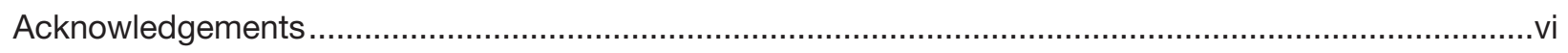

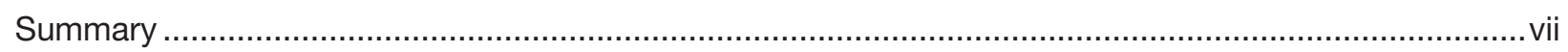

1. Soil biodiversity, soil organic matter and soil organic carbon: introduction and overview.................... 1

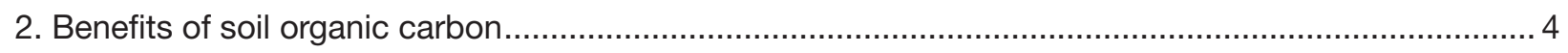

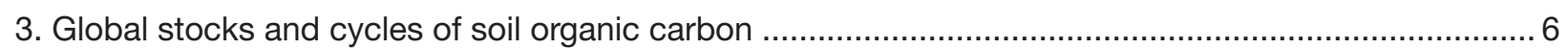

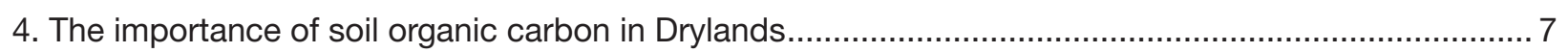

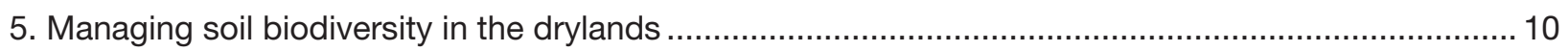

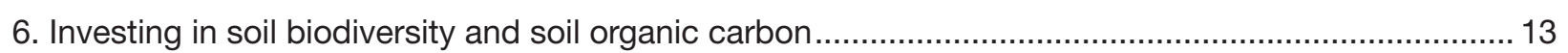

7. Policy options to conserve soil biodiversity and soil organic carbon .............................................. 16

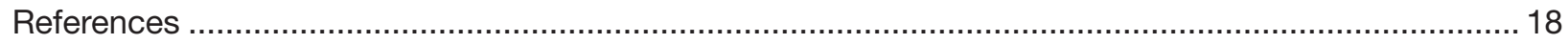

Endnotes 


\section{List of figures}

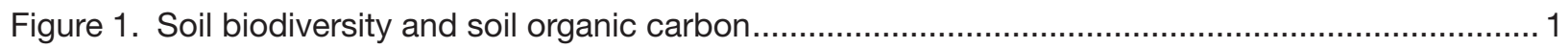

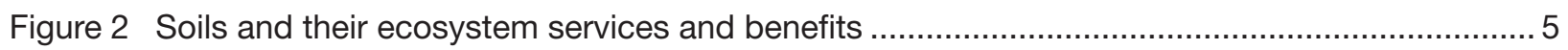

Figure 3. The vast extent of the world's drylands is significant for the total stock of accumulated SOC.

(a) Drylands systems and their spatial distribution (Source: MEA);

(b) SOC content to $1 \mathrm{~m}$ depth in tons per hectare (Batjes 2016)

\section{List of boxes}

Box 1. Role of soil fauna for nutrient and water cycling in the drylands ......................................... 2

Box 2. Ecosystem services supported by increased Soil Organic Carbon ......................................... 4

Box 3. Multiple benefits of achieving the Sustainable Development Goals ........................................ 4

Box 4. Investing in SOC for climate resilience - Australia............................................................... 6

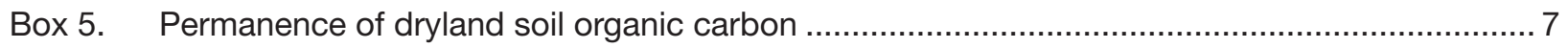

Box 6. Investing in SOC and rangelands for livestock and water security - West Asia ..................... 11

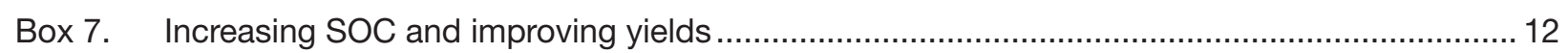

Box 8. Incentives to invest in SLM are often other than financial ................................................ 13

Box 9. Investing in SOC and agroforestry for food production - Africa ......................................... 13

Box 10. Large scale landscape restoration in China ........................................................................ 14

Box 11. Funding external benefits from sustainable dryland agricultural management in Australia...... 14

Box 12. The case of sustainable rangeland investments in Portugal............................................... 15

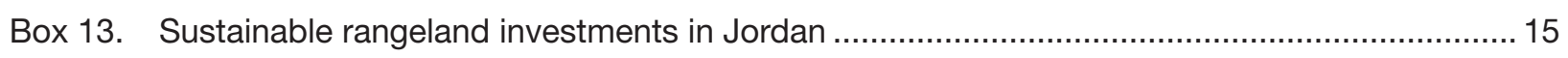




\section{Foreword}

Soil forms a thin and yet vital membrane covering the non-submerged surface of our planet. It drives the carbon, nitrogen and water cycles upon which life on earth depends and is home to an immense diversity of species, all of which contribute invaluable, life-giving services to society.

But soil is as fragile as it is abundant. A growing human population is driving increased demands for food, fibre and fuel which is in turn putting an unsustainable strain on the world's soils. So much so that, today, up to 33 percent of land is moderately to highly degraded due to erosion, salinization, compaction, acidification, and chemical and other contaminants of soils.

The health of soils is finally gaining the needed attention in global and national discussions, most notably in its inclusion in the Sustainable Development Goals under target 15.3 (Land Degradation Neutrality) and other global targets set under the United Nations Convention to Combat Desertification.

Soil Biodiversity and Soil Organic Carbon: Keeping Drylands Alive builds on the growing discourse on soil stewardship and further strengthens the underlying message that soil is a public good which requires economic valuation and related institutional arrangements to protect it for the overall welfare of society. This technical brief outlines a number of operational considerations, drawing-upon practical experiences and lessons from across the globe, and demonstrates that a multitude of development wins could be gained from sustainable land management.

We are confident that this brief will provide an invaluable resource for practitioners and policy-makers looking to move from theory to practical management of our soils.

Acknowledging that there is still a long way to go, and as this Technical Brief highlights, we feel that we are today in a strong position to turn the growing global awareness into action, and collectively work to arrest the decline of this magical, life-giving resource.

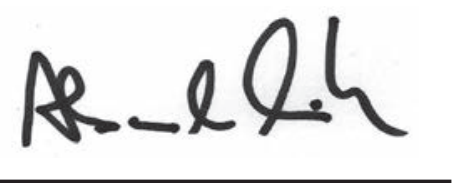

Alexander Müller Managing Director TMG - Töpfer Müller Gaßner Thinktank for Sustainability Berlin, Germany

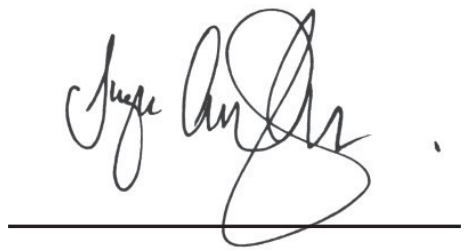

Inger Andersen Director General IUCN 


\section{Acknowledgements}

This document was informed by a report written by Cameron Allen, entitled Report on Soil Organic Carbon and Soil Biodiversity in Drylands (July, 2017). The work was strengthened by contributions from Claire Ogali, Guyo Roba and Razingrim Ouedraogo of IUCN.

The report was peer reviewed by Alexander Mueller and Dr Martial Bernoux. External reviews were also provided by Kirk Olsen, Patrick Gonzales and Jonathan O'Donnell of the IUCN World Commission on Protected Areas and the lan Hannam of the IUCN World Commission on Environmental Law.

The report was made possible by the support of the Agence Francaise de Développement. 


\section{Summary}

By the year 2050 the global population is projected to be 9 billion and the world will need to produce an estimated $60 \%$ more food, while 1.8 billion people will be living in water scarce areas. While food production is increasing globally, the land on which agriculture depends is degrading at an alarming rate, jeopardising future progress.

Soil biodiversity and soil organic carbon are vital to the way ecosystems function and they largely determine the role of land in producing food, storing water, and mitigating climate change. They are the key to unlocking the multiple economic and environmental benefits - the multi-functionality - of land.

Globally, soil biodiversity has been estimated to contribute between US\$1.5 and 13 trillion annually to the value of ecosystems services. Yet despite its global importance, soil biodiversity is often neglected in public policy and is being lost at a considerable rate through unsustainable land management practices, soil erosion and other land degradation processes. Between one quarter and one third of all land worldwide is estimated to be degraded, resulting in lower agricultural production, disrupted water cycles, and release of sequestered greenhouse gases.

\section{Impacts of land degradation}

\section{Climate change mitigation}

- Global stocks of soil organic carbon are estimated to be greater than the combined carbon in the atmosphere and terrestrial vegetation. When soil is eroded, SOC is redistributed and some is lost.

\section{Food production}

- Land degradation and climate change could reduce agricultural yields and result in a food production shortfall of 25 per cent.

\section{Water storage}

- Soil stores two thirds of the fresh water on the planet and this role is determined by the level of organic matter in the soil.

Dryland soils make an important contribution-roughly one third-to global stocks of soil biodiversity and soil organic carbon, and they can contribute strongly to global food production and to climate change mitigation. They account for $42 \%$ of the world's land, providing $44 \%$ of all cultivated land and $50 \%$ of the world's livestock. Drylands are particularly valuable for carbon storage due to their high degree of permanence-the duration that carbon is stored in the soil-compared to humid areas.

The proportion of degraded land in the drylands is similar to the global proportion, but the solutions may be different to those suitable for more humid lands. The comparatively high level of poverty and underdevelopment in drylands means that drivers of degradation are different and the nature of policies and investments to address desertification should differ accordingly.

Restoring or preserving soil biodiversity and soil organic carbon requires increased inputs of organic matter or a reduction of carbon losses, or both. It is particularly important to maintain soil organic carbon (SOC) and to increase it where possible. In dryland soils SOC levels are often low and close to the tipping point where restoration is no longer possible, giving way to irreversible land degradation. However, measures to increase soil biodiversity and SOC can take many years. Restoration of degraded land can be costly and it is preferable to avoid degradation in the first place, through adoption of sustainable land management practices and protection of sustainably managed agricultural landscapes.

Many farming practices are known to increase soil biodiversity and SOC, mostly revolving around integrated management of soil water and nutrients, erosion control measures, and maintaining groundcover. Sustainable farming practices that have been used widely in the drylands include agroforestry, conservation agriculture and pastoralism. However, adoption or maintenance of these practices is low in the world's poorest drylands, where population growth and the demand for greater agricultural productivity and water security are highest. These regions will face future land degradation unless sustainable land management becomes central to agricultural development programs. 
Sustainable land management often demands investment of labour and energy and requires new skills, knowledge, equipment and inputs. Innovative policies and investments are therefore needed to encourage adoption by land users. An important part of the solution lies in rewarding or otherwise incentivising the multiple benefits of sustainably managed land, or "multi-functionality", at scale, rather than maximising individual goods or services. This includes those values that are enjoyed as externalities by the wider society.

The 2030 Agenda for sustainable development increases the demand on soils to provide food, water and energy security, protect biodiversity, and mitigate climate change, increasing the centrality of soils in global environmental and development politics. Target 15.3 on Land Degradation Neutrality, reflects the growing awareness that land, and by extension soil biodiversity and soil organic carbon, is both a natural resource and a public good that underpins wider sustainable development.

For good governance of our shared Land Resources, governments should aim at protecting and promoting the multi-functionality of land: to ensure that land users employ sustainable approaches that are measured against the delivery of multiple goods and services. Achieving this goal requires a number of priority measures:

1. Evaluate land management against the sustainable delivery of multiple goods and services;

2. Build on policies and legislation to enable scaling-up of sustainable land management and landscape restoration or rehabilitation;

3. Enhance local governance mechanisms that support land users in sustainable land management practices;

4. Strengthen land information to support landscape-scale planning and monitoring;

5. Establish effective extension services that support land users to adopt sustainable land management practices;

6. Create enabling conditions for private investment in sustainable land management. 


\section{Soil biodiversity, soil organic matter and soil organic carbon: introduction and overview}

Soils are some of the most species-rich habitats on earth, home to an abundance of species that enable soils to function and develop. Many of these species are essential for the functional diversity and resilience of the soil and the ecosystems that depend on the soil. Soil Biodiversity is an indicator of soil quality: a higher species diversity results in greater soil stability in terms of its capacity to perform key functions such as cycling of nutrients, assimilation of organic wastes, and maintenance of soil structure'.

Soil Biodiversity, soil organic carbon and soil organic matter are closely related but distinct (Figure 1). Soil Biodiversity reflects the mix of living organisms in the soil, including bacteria, fungi, protozoa, insects, worms, other invertebrates and vertebrates. These organisms interact with one another, as well as with plants and small animals, forming a web of biological activity2. Most species live in the top 2-3 cm soil layer, where organic matter and root concentrations are highest. Biological soil crusts, for example, are communities of mosses, lichens, and microorganisms at the soil surface that particularly conserve soil fertility in drylands worldwide ${ }^{3}$.

Soil services

Above ground biodiversity

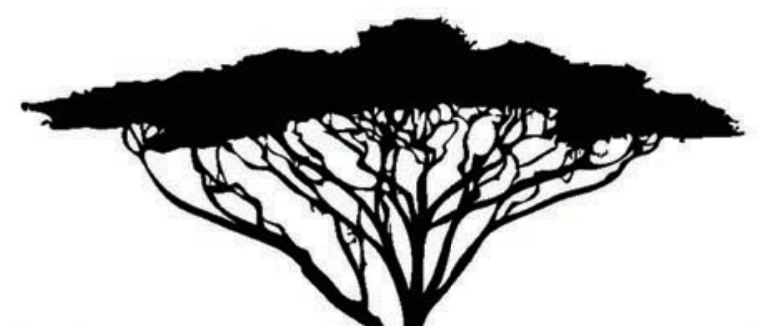

Plant production

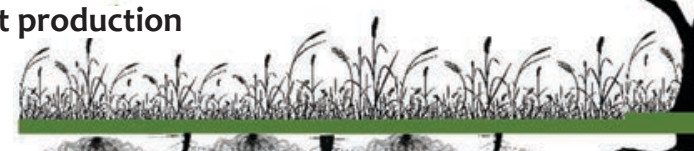

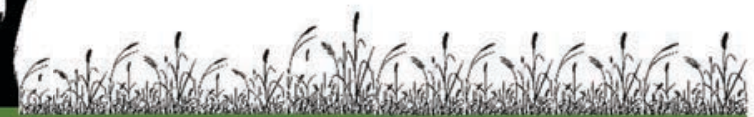
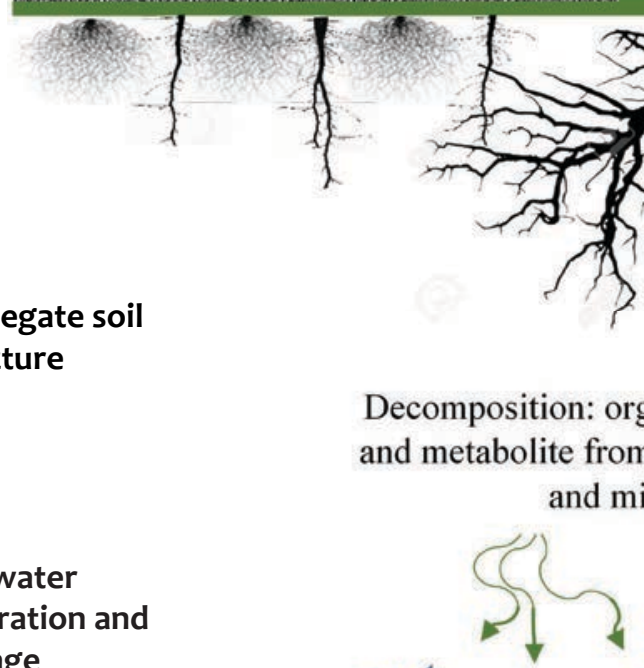

infiltration and storage

Soil fertility
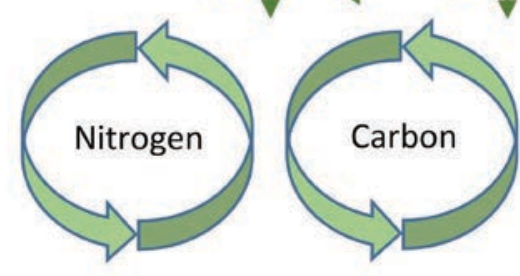

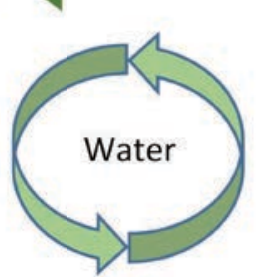

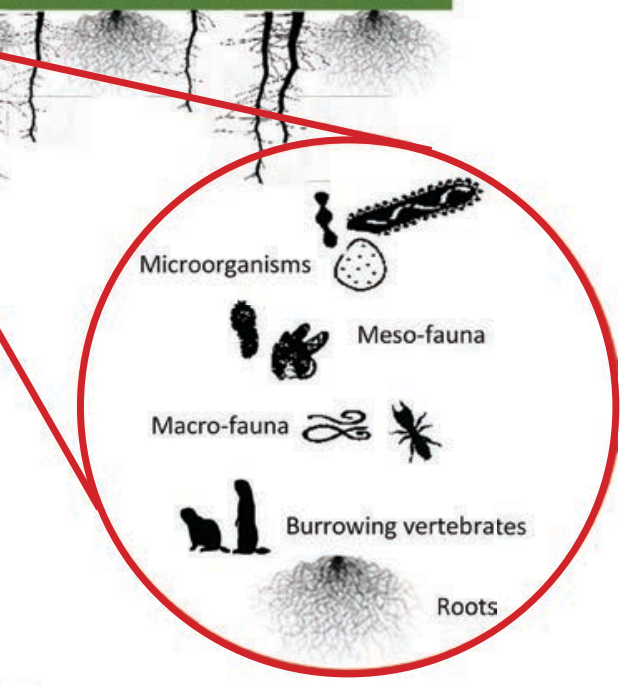

Below ground biodiversity

Figure 1. Soil biodiversity and soil organic carbon 
Broadly interpreted, Soil Organic Matter (SOM) encompasses all of the organic components of a soil, including living biomass (intact plant and animal tissues and microorganisms), dead roots and other plant residues and dead tissue, and soil humus. SOM and the debris of dead tissues left by plants and animals (detritus) is essential for biological activity in the soil and is the main source of energy, nutrients and habitat for the vast majority of soil organisms. Soil Organic Carbon makes up approximately $50-60 \%$ of SOM. An estimation of SOM is usually made by measurement of SOC, with application of a factor of 1.9 to 2 for converting SOC to $\mathrm{SOM}^{4}$.

In dryland areas, such as the Sahel, the Middle East, or Australia, most biodiversity is found beneath the soil's surface and conserving it is crucial for water and food security, as illustrated in Box 1.

\section{Box 1. Role of soil fauna for nutrient and water cycling in the drylands}

Insects are important for nutrient and water cycling in drylands. For instance, dung beetles, in the insect families Scarabaeidae and Geotrupidae, play a major role in the productivity of many grasslands. These beetles enrich soil nutrients, aerate the soil, and improve soil porosity and drainage by burying animal faeces. Termites play a similarly crucial role, particularly in Savannas of Africa, Australia and South America, by altering soil properties and creating "islands of fertility" that enhance plant growth. Termite mounds increase heterogeneity within the landscape and play a major role in nutrient cycling and infiltration of water ${ }^{5}$. This contributes to ecosystem resilience, helping dryland ecosystems recover from drought, and stabilizing them in the face of climate change.

Land in arid and semi-arid ecosystems frequently is found with a biological soil crust, consisting of communities of living organisms that live on the soil, or within the top few millimetres. This crust is an association between cyanobacteria, algae, microfungi and other species, and soil particles. Biological soil crusts play a number of ecological roles, including carbon and nitrogen fixation and soil stabilization. They also affect water infiltration and seed germination and other properties that may have positive or negative implications for land productivity and vegetation growth. Biological soil crusts are more likely to form when vegetation cover is reduced, since cyanobacteria require solar energy to photosynthesise. They can therefore be a symptom of land degradation, but they can also stabilise soils and reduce further degradation ${ }^{6}$.

Soil biodiversity contributes to the development of above ground vegetation by decomposing plant residues, a process that converts organically-held nutrients into organic and mineral forms available for renewed plant uptake (e.g. nitrogen) ${ }^{7}$. Soil biodiversity increases soil resilience, in terms of its capacity to 'bounce back' to functional health after a severe disturbance. The contribution of soil biodiversity to ecosystem services globally has been estimated at between USD 1.5 and 13 trillion annually 8 .

Soils are complex ecosystems and soil organisms and mineral components interact to generate high diversity and complexity. Soil mineral composition and soil organisms together determine soil structure and fertility. Soil mineral composition in turn depends on soil formation factors such as parent material, relief, climate, hydrology, biological organisms, and time. The capacity of soil to retain moisture is to a large extent determined by SOM/SOC and soil structure. Water that is stored in soils serves as the source for 90 percent of the world's agricultural production and represents about 65 percent of global fresh water ${ }^{9}$. Indeed, one study has indicated that each loss of $1 \mathrm{~g}$ of SOM decreases soil available moisture content by 1 to $10 \mathrm{~g}^{10}$. Plant productivity (for agricultural productivity and biodiversity) depends hence directly on soil organisms, which regulate nutrient availability and uptake, maintain soil structure, and regulate hydrological processes ${ }^{11}$.

The amount and quality of SOM and SOC are therefore major drivers of biodiversity in the soil, providing a source of energy and food for microorganisms that are essential to biological processes in the soil. In turn, soil biodiversity contributes to the formation of SOM through decomposition and the production of humus. These many different interactions are complex and create multiple biological, chemical and physical reinforcing feedback loops.

Soils with high organic matter content are capable of supporting greater vegetation diversity, which in turn increases SOM and SOC, while enhancing soil biodiversity. Although few studies have quantified these effects $^{12}$, recent research has utilised SOC as a proxy for SOM and SBD, demonstrating that even marginal reductions in SOC content in the order of 1 per cent can have a significant negative impact on soil natural capital and ecosystems services ${ }^{13}$. 
The importance of soil organic carbon for positive environmental and development outcomes has gained recognition as a result of breakthrough decisions at the twelfth session of the Conference of Parties (COP) of the United Nations Convention to Combat Desertification (UNCCD) in October 2015. Soil organic carbon is recognised as a major determinant of agricultural productivity and water security, and it is the cornerstone of biodiversity and climate change resilience. This importance is reflected in Target 15.3 of the Sustainable Development Goals to achieve a land degradation-neutral world, and notably by one of its three indicators: "trends in carbon stocks above and below ground", for which the metric is soil organic carbon stocks. However, there is insufficient convergence of the many difference branches of science, practice and policy that deal with soil organic carbon and its relationship with biodiversity. As a result the multiple benefits of soil organic carbon are easily ignored and risk being lost.

This Technical Brief was developed to address the gap in awareness of the relationship between soil biodiversity and soil organic carbon, particularly in drylands, and the role of soil biodiversity in the provision of ecosystem services. The Technical Brief is written for technical advisors to ministries responsible for environment, agriculture and natural resources. This encompasses scientists, policy advisors, and Civil Society groups, many of whom are familiar with the broad subject area but will not be up to date with the latest research on soil biodiversity and soil organic carbon.

The Technical Brief builds on two earlier IUCN Technical Briefs on Rangelands and on Land Degradation Neutrality ${ }^{14}$. It synthesises key research on dryland soil biodiversity and provides supporting examples in brief case studies, with links for further information. Lessons are drawn from this information and the main recommendations that emerge are provided in the concluding section. The information compiled in this report is drawn from a longer background paper entitled "Soil Organic Carbon and Soil Biodiversity in Drylands" written by Cameron Allen and pending publication on the IUCN website. 


\section{Benefits of soil organic carbon}

The benefits of soil carbon, and by extension soil biodiversity, are widely described in the literature. Increasing SOC enhances soil quality and fertility, improving soil productivity, vegetation growth and promoting further accumulation of carbon in the soil. Increasing the quantity and quality of soil organic carbon improves soil structure stability, water retention capacity, porosity, and soil fertility ${ }^{15}$. This in turn leads to improving a wide range of ecosystem services (Box 2 and Figure 2).

\section{Box 2. Ecosystem services supported by increased Soil Organic Carbon}

1. Increased crop yields and higher food production (up to 2.3 billion tons of additional crop production per year, equivalent to USD 1.4 trillion $)^{16}$

2. Increased soil water holding capacity, water infiltration and storage

3. Greater above and below-ground biodiversity (global contribution of soil biodiversity to ecosystem services is estimated at USD 1.5 to 13 trillion annually) ${ }^{17}$

4. Carbon storage and climate regulation (at least half of emissions reductions needed to reach the 2 degree goal agreed to by the international community could come from land sectors of major emitting countries that possess substantial parts of the drylands $)^{18}$

The value of soil biodiversity is often only appreciated after it has started to decline. The loss of organic carbon from soils, especially when initial levels are low as is the case in dryland regions, invariably results in the degradation of soils and their associated ecosystem functions. Between one quarter and one third of all land worldwide is estimated to be affected by some form of land degradation ${ }^{19}$, that is contributing to declines in agricultural production, disruption of water cycles, release of greenhouse gasses, and many other costs to society. These negative impacts have to be seen in a perspective where the human population is estimated to require an additional $60 \%$ of food by the year 2050 and by 2025, 1.8 billion people are projected to be living in areas with absolute water scarcity. Land degradation and climate change could reduce agricultural yields and result in a food production shortfall of 25 per cent ${ }^{20}$.

Soil biodiversity and soil organic carbon are therefore an important foundation of a broad range of ecosystem services across all four standard ecosystem service categories (see Figure 2). It is therefore key to the multifunctionality of a landscape, and the reason why strengthening investment and legislation in sustainable land management is considered to be central to achieving many of the Sustainable Development Goals (see Box 3). SDG Target 15.3 aims to achieve a Land Degradation Neutral World by the year 2030, by maintaining and increasing the amount of healthy and productive land resources.

\section{Box 3. Multiple benefits of achieving the Sustainable Development Goals}

Sustainable land management can contribute to several SDGs simultaneously, including poverty eradication (Goal 1), food and water security (Goals 2 and 6), biodiversity protection (Goal 15), and climate change mitigation and adaptation (Goal 13). For example, research has estimated that restoring only $12 \%$ of degraded agricultural land could boost smallholders' incomes by USD 35-40 billion per year and help to feed an additional 200 million people annually within 15 years, while increasing resilience to drought and water scarcity and reducing GHG emissions ${ }^{21}$. 


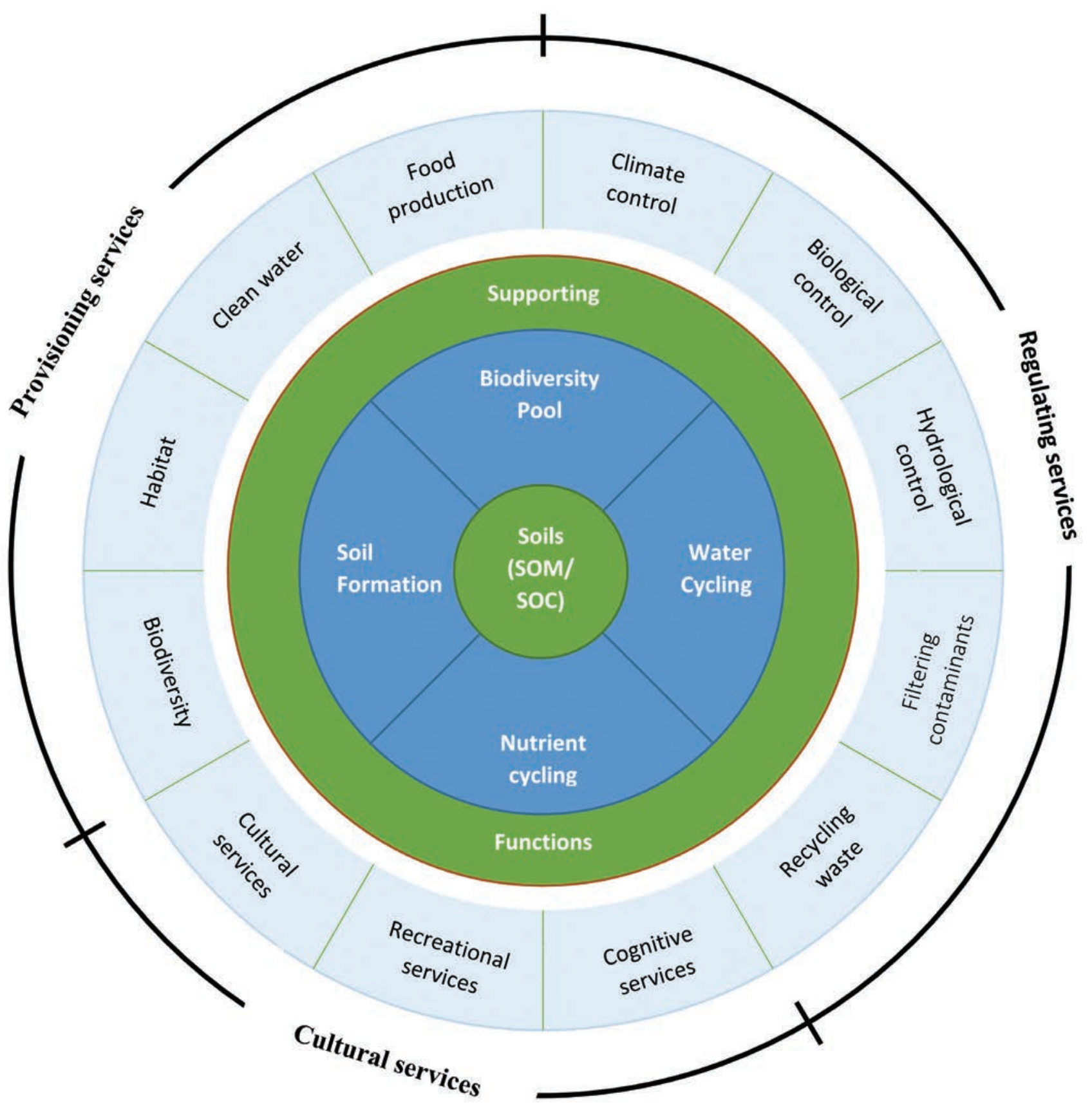

Figure 2 Soils and their ecosystem services and benefits 


\section{Global stocks and cycles of soil organic carbon}

$\mathrm{SOC}$ is part of the much larger global carbon cycle. The reservoir of SOC is not static, and it is constantly cycling between different carbon pools of soil, vegetation, ocean and the atmosphere. Soil is the second largest carbon stock after oceans, and accounts for one third of the global carbon stock ${ }^{22}$. Considerable variation across estimates notwithstanding, global SOC stocks have been estimated at around $1500 \mathrm{GtC}$ in the first meter of soil, which is more than is contained in the atmosphere (800 GtC) and terrestrial vegetation (500 GtC) combined ${ }^{23}$.

The spatial and temporal magnitude of SOC storage varies widely, and is determined by different abiotic and biotic factors, including soil type, land use and climatic conditions ${ }^{24}$. The largest SOC stocks are located in areas such as wetlands and peatlands, most of which occur in regions of permafrost and in the tropics ${ }^{25}$.

Organic carbon in soils is a continuum which can be conceptually divided into different pools. Most approaches consider three pools which are a function of their physical and chemical stability: fast pools (labile or active pools with turnover of 1-2 years); intermediate pools (partially stabilized pools with turnover of 10-100 years); and slow pools (refractory or stable pools with very slow turnover of 100-1000 years) ${ }^{26}$. The fast or labile proportion, the vital part of SOC, is considered important in terms of influencing soil health and SOC sequestration, while the slow or stable fraction of SOC contributes to the soil's nutrient holding capacity as well as to long-term carbon sequestration ${ }^{27}$.

SOC levels reflect a dynamic equilibrium between inputs of fresh organic carbon and emissions of respired carbon to the atmosphere, and of dissolved and particulate organic carbon entering surface or ground waters. Soil erosion results in the redistribution of SOC at local, landscape and regional scales. Restoring or preserving SOC in soils requires increased inputs of organic carbon or a reduction of losses, or both. However, the impacts of such changes can take years to eventuate, with the effects of past land use and management practices influencing trends in SOC levels decades after new ones have been introduced ${ }^{29}$.

\section{Box 4. Investing in SOC for climate resilience - Australia}

In the southwest of Western Australia, the marginal value of SOC in cropping systems (i.e. the value of a soil with $1 \mathrm{t} \mathrm{C/ha} \mathrm{more} \mathrm{SOC} \mathrm{as} \mathrm{compared} \mathrm{against} \mathrm{a} \mathrm{standard} \mathrm{soil)} \mathrm{has} \mathrm{been} \mathrm{estimated} \mathrm{at} \mathrm{5.6-6.9} \mathrm{US \$ /t}$ $\mathrm{C} / \mathrm{ha} /$ year, depending on rainfall zone and crop type. Approximately $75 \%$ of this agronomic benefit value is the estimated carbon sequestration value, $20 \%$ is the nitrogen-replacement value, and $5 \%$ is the estimated productivity improvement value. Value (AU\$1 = approximately US\$0.75) ${ }^{28}$. 


\section{The importance of soil organic carbon in Drylands}

Drylands encompass some of the world's most important land use systems and significant biological diversity. They support over 2 billion people and $25 \%$ of the world's endangered species ${ }^{30}$. Globally, dryland ecosystems cover approximately $42 \%$ of the Earth's surface, including some of the world's most threatened ecosystems ${ }^{31}$ (Figure 3). They provide $44 \%$ of the world's cultivated land, $50 \%$ of the world's livestock ${ }^{32}$, and contain a variety of important habitats for vegetable species, fruit trees and micro-organisms ${ }^{33}$. Drylands are home to many of the most biologically and culturally diverse habitats on the planet, featuring high levels of species endemism and natural heritage ${ }^{34}$.

Drylands are tropical and temperate areas with an aridity index ${ }^{1}$ of less than 0.65 , where average rainfall is less than the potential moisture losses through evaporation and transpiration ${ }^{35}$. Using the aridity index, four categories of drylands can be distinguished: dry sub-humid, semi-arid, arid, and hyper-arid lands. Whereas crop lands are generally restricted to the least arid drylands, rangelands account for about three quarters of the drylands. Rangelands include grass-dominated biomes, but also contain a considerable amount of woody biomass, particularly in the sub-humid and semi-arid zones ${ }^{36}$. About $72 \%$ of drylands occur in developing countries and this proportion increases with aridity: almost all hyper-arid lands are in the developing world ${ }^{37}$.

At first glance, the global importance of drylands for storage of soil organic carbon may not be apparent. The scarcity of water in drylands constrains plant productivity, which affects SOM and SOC accumulation in soils. As a result, dryland soils typically have low organic carbon content, often less than $1 \%$ of the soil mass. In grassland or forest soils SOC may be as high as 4-5\% but cultivation of the soil acts to release its stored carbon; in temperate zones SOC is around $1-2 \%$ in cultivated soils.

Due to their vast extent, the total stock of accumulated SOC in drylands is significant, accounting for around $30 \%$ of the global total SOC stocks, i.e. roughly $450 \mathrm{GtC}$ or about as much as the organic carbon stocked in all terrestrial vegetation ${ }^{38}$. Furthermore, the residence time of carbon in dryland soils is extended due to their aridity and is much longer than in other soils ${ }^{39}$ (Box 5). The spatial extent of drylands, combined with the substantial area that is affected by land degradation, means that drylands will play a critical role in the global effort to sequester atmospheric carbon and reduce the magnitude of anthropogenic climate change.

The potential for sequestering carbon within soils is related to soil carbon saturation (or maximum carbon stabilization capacity), which is the point at which further carbon inputs to the soil will not further increase soil carbon stock ${ }^{41}$. The conditional state of dryland soils is reported to be far below their maximum carbon saturation point, due mainly to their aridity and therefore their comparatively low overall productivity. Additionally, since land degradation affects between one quarter and one third of the drylands, large areas are likely to have further depressed levels of SOC.

\section{Box 5. Permanence of dryland soil organic carbon}

Permanence relates to the longevity of the carbon stock, i.e. how long the increased SOC remains in the soil. SOC constantly cycles between the fast pool, with low permanence but greatest influence on soil health, and the slow pool, which has greatest permanence and nutrient holding capacity. The means through which soil carbon stocks are increased, such as manuring or afforestation, may affect the subsequent rate of loss of carbon from the soil, and hence the permanence of the stock. However, the differences may be small compared to the loss that can occur as the result of extreme change in land-use or land management ${ }^{40}$. 

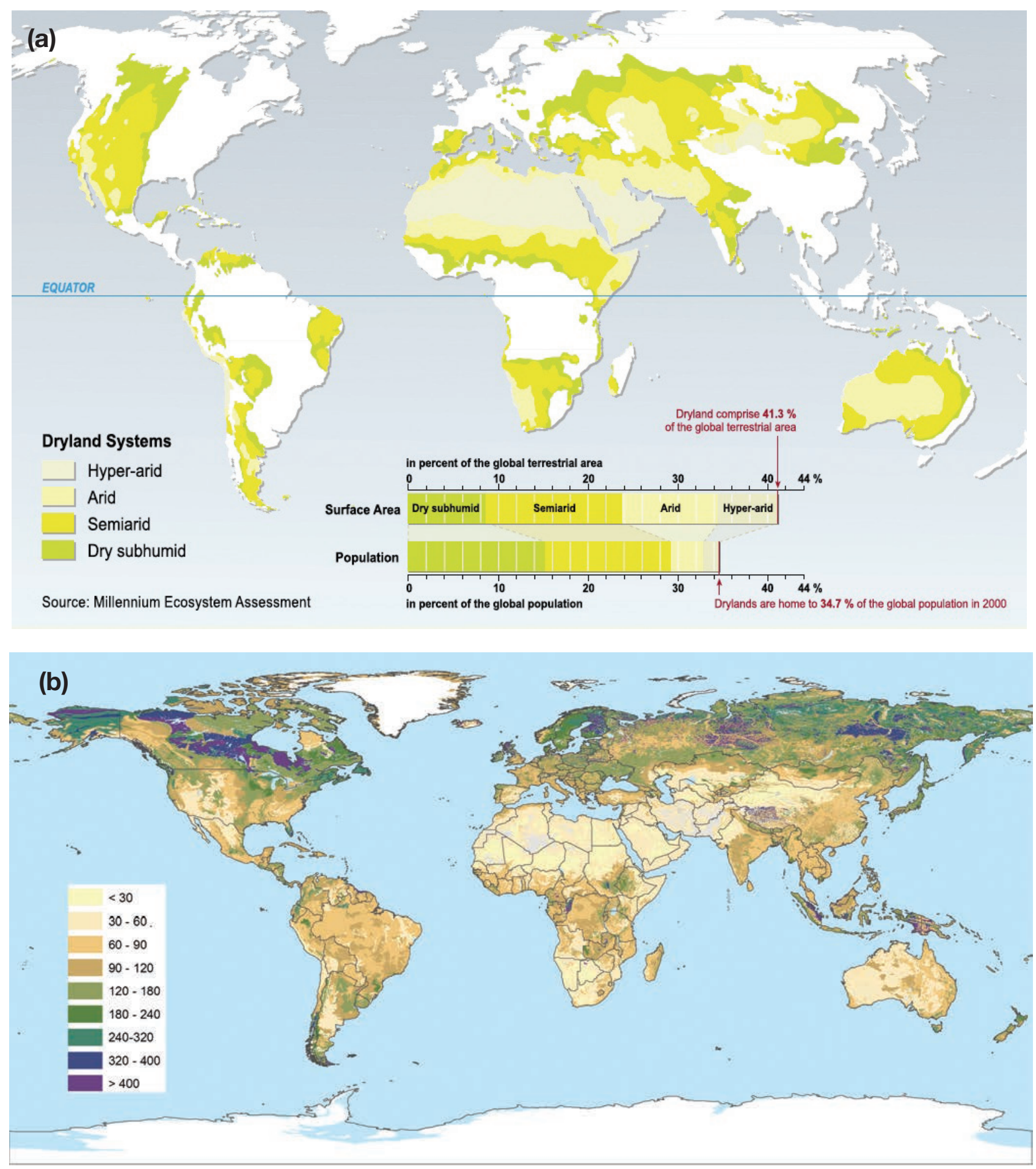

Figure 3. The vast extent of the world's drylands is significant for the total stock of accumulated SOC. (a) Drylands systems and their spatial distribution (Source: MEA); (b) SOC content to $1 \mathrm{~m}$ depth in tons per hectare (Batjes 2016) 
Soil biodiversity and soil organic carbon can be restored through the application of organic matter or through reduction in carbon losses, or both. This is urgently needed in degraded dryland soils, which are often low and close to the tipping point where restoration is no longer possible, and where there is a risk that land degradation becomes irreversible. However, measures to increase soil biodiversity and soil organic carbon can take many years. Restoration of degraded land can also be costly and it is preferable to avoid degradation in the first place, through adoption of sustainable land management practices and protection of sustainably managed agricultural or pastoral landscapes.

Dryland soil quality and productivity can be improved by enhancing soil organic matter content (and hence SOC levels) through alternative management practices like reduced tillage ${ }^{42}$ and sustainable pasture management. Research on community-protected rangeland sites in Jordan has demonstrated the potential for increasing biomass production on degraded lands that can increase $\mathrm{SOC}^{43}$. Provided there is careful grazing management many investigations have found a positive effect of grazing on the stock of soil carbon in drylands ${ }^{44}$.

If dryland soils are naturally far below their maximum carbon saturation point, raising SOC levels beyond the natural state may require substantially altering natural conditions and ecosystem characteristics; for example by using irrigation and afforestation. Such approaches have been proposed as solutions for sequestering atmospheric carbon, although further understanding is needed of the potential risks to permanence (as a result of increased soil moisture) as well as possible impacts on dryland biodiversity.

Tropical grasslands, which account for a large proportion of the drylands, appear to have higher carbon sequestration potential than was previously thought ${ }^{45}$. One estimate is that grasslands globally store about 343Gt C: almost $50 \%$ more than is stored in forests worldwide ${ }^{46}$. Africa's grasslands, for example, could sequester between 0.007 and $0.042 \mathrm{Gt} \mathrm{C}$ year/147. Conversion from grassland to annual crops can lead to a $60 \%$ loss of soil carbon stocks and a $95 \%$ loss of above ground carbon ${ }^{48}$.

Drylands possess a high potential for increased carbon sequestration and some organisations refer to drylands as carbon sequestration 'bright spots'. Although there are remaining questions over the best practice in each location, drylands should be considered key areas for investments in sustainable management of carbon stocks. Such investments need to be actively managed to restore, preserve and increase their soil organic carbon levels and foster their sequestration potential ${ }^{49}$. 


\section{Managing soil biodiversity in the drylands}

The 2030 Agenda for Sustainable Development increases the demand on soils to provide food, water and energy security, protect biodiversity and mitigate climate change. This is increasing the centrality of soils in global environmental and development politics. This has in turn led to the notion of "soil security" or "soil health". Soil security is concerned with the maintenance and improvement of the world's soil resources to produce food, fibre and freshwater, contribute to energy and climate sustainability, and maintain the biodiversity and the overall protection of the ecosystem ${ }^{50}$.

SOC can be considered as a universal indicator of soil security or soil health. Reductions in SOC will also reduce soil security/health and the benefits it can provide. Factors that influence SOC sequestration in soils include climate, soil type, vegetation cover and management practices. In the drylands, the role and benefits of SOM and SOC are particularly related to their physical, biological and chemical properties ${ }^{51}$.

There are different ways of ensuring that land or ecosystem management is sustainable; these can be categorized as either direct land use actions (measures undertaken by land users) or enabling measures (taken by 'facilitators' to promote or enhance the adoption of direct land use actions). A variety of land management techniques can preserve or increase soil organic carbon, which primarily require effective organic matter and water management in order to maintain a sufficient level of fertility for sustainable food production ${ }^{52}$. Many of these practices deliver multiple benefits, for example increasing food productivity, water resources, and biodiversity, as well as mitigating and adapting to climate change.

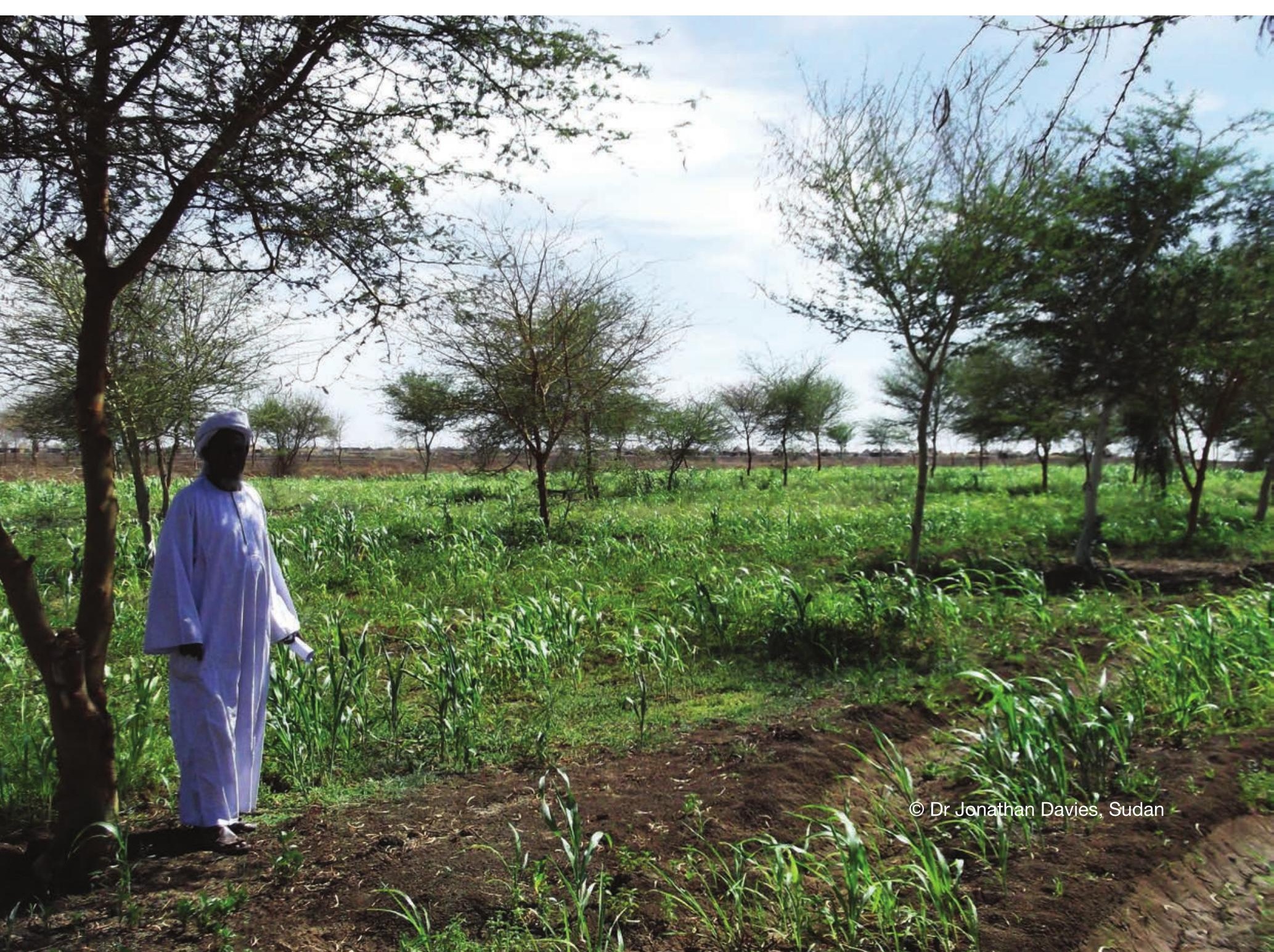




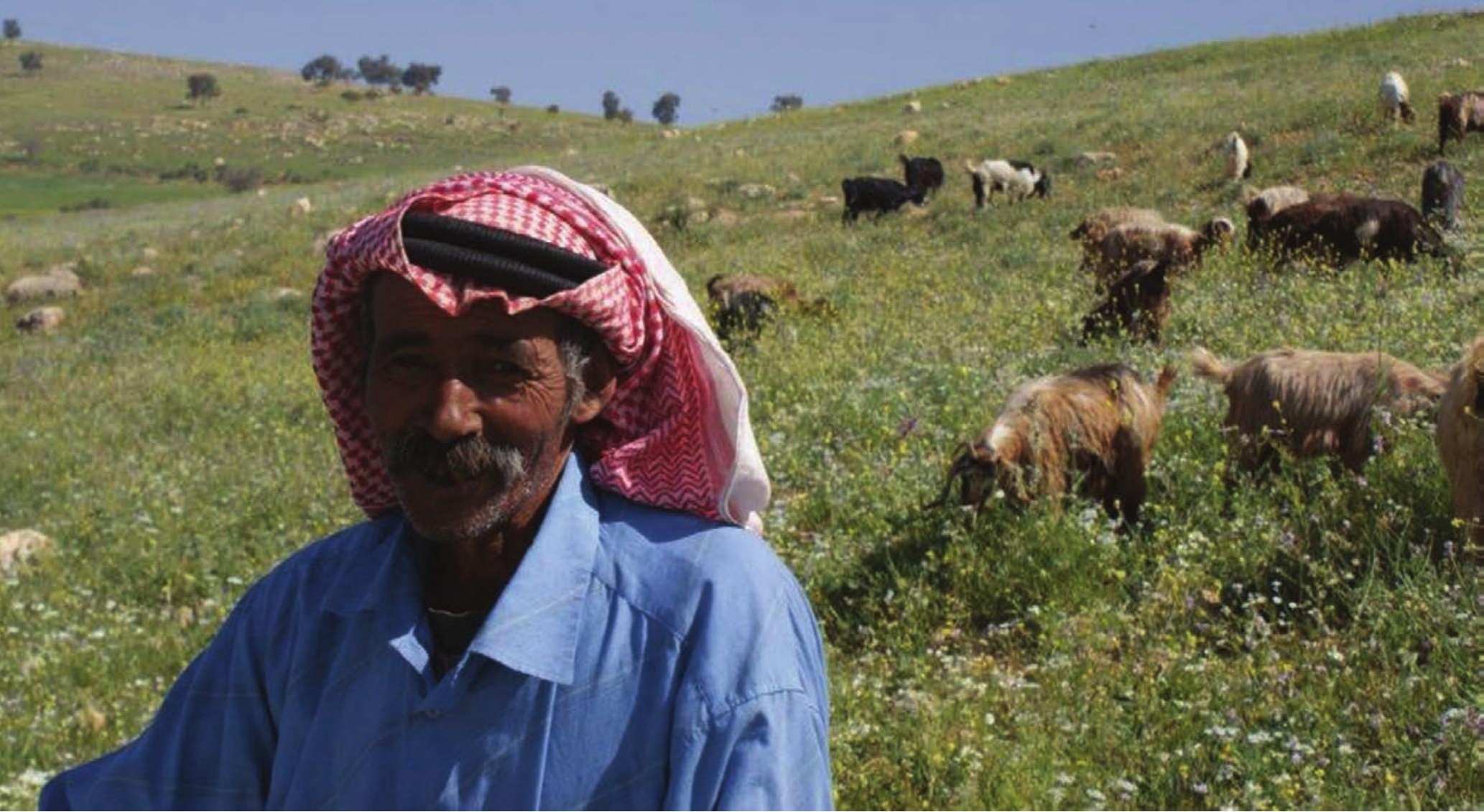

Most good practices in soil organic carbon management revolve around integrated water and nutrient management, erosion control measures, and maintaining groundcover ${ }^{53}$. For example, Conservation Agriculture ensures minimum tillage, soil mulching and crop rotation, which combine to increase soil organic matter and fertility ${ }^{54}$. Sustainable Rangeland Management emphasises managing the duration, timing and intensity of grazing to ensure optimal herbivore impact, such as seed dispersal, manuring, and removal of dead vegetation ${ }^{55}$. Agroforestry is a system in which trees or shrubs are grown among crops or pastureland to increase the productivity, diversity and resilience of farms ${ }^{56}$. These practices all apply principles of synergy and complementarity in order to conserve soil structure, soil moisture and nutrients ${ }^{57}$ and eventually increase carbon storage ability.

\section{Box 6. Investing in SOC and rangelands for livestock and water security - West Asia}

In Jordan, community based rangeland management is being scaled up as a way to restore and protect land and biodiversity. Geospatial analysis and feasibility studies on vegetation regrowth under community protection indicates that rangeland restoration in Jordan can be achieved on an estimated $23,470 \mathrm{~km}^{2}$ of rangelands, or about $30 \%$ of the country's total rangeland area. The studies also show that investments in sustainable range management (SRM), soil and water conservation, ecological livestock production, herbs and medical plants, eco-tourism and renewable energies can contribute to biomass and fodder increase, ground water recharge, reduced siltation of water reservoirs, carbon sequestration and biodiversity conservation. Economic valuation indicates that SRM in these rangelands would increase forage production by an estimated with 9.45 million US\$, and ground water recharge by 11 million US\$ per year ${ }^{58}$. 
There is considerable disagreement over how to protect and restore grassland SOC, particularly in relation to the positive and negative impacts of herbivores on grassland ecology. Some authors report an increase in SOC stock with intensively managed grasslands ${ }^{59}$ whilst others report that SOC can be increased by reducing or excluding grazing ${ }^{60}$. Ultimately the influence of grazing on SOC may be largely determined by the type of grazing management, with high levels of permanent grazing particularly injurious. Where grazing patterns incorporate periods of rest and recovery for pastures the impact can be more positive. For example, rotational grazing has been found to increase SOC compared to low-intensity continuous grazing ${ }^{61}$. Highly intensive grazing can also negatively affect soil structure and soil organic matter by compacting the soil surface.

Effective pasture management typically synchronises grazing with the growth cycle of grasses, harnessing the positive role herbivores play in selecting and distributing palatable species, and modifying the physical and chemical properties of the soil ${ }^{62}$. Pasture management also affects the nitrogen cycle, since herbivores return digestible $\mathrm{N}$ at high concentrations in urine patches ${ }^{63}$. Fire management and fertilization have also been proposed as ways to increase carbon sequestration in grasslands, but in practice most of the potential sequestration in non-degraded grasslands is through changes in grazing practices.

Although these land management approaches are still struggling to find favour in some countries, it should also be noted that they have been widely adopted in others. For instance, an estimated 558 million people worldwide utilise agroforestry systems on 43 percent (over 1 billion ha) of all agricultural land, including 320 million ha in South America, 190 million ha in sub-Saharan Africa, and 130 million ha in Southeast Asia ${ }^{64}$. Agroforestry is not exclusive to drylands, but it is proving popular for protection and restoration of degraded land in a growing number of dry countries.

\section{Box 7. Increasing SOC and improving yields}

Adoption of sustainable management practices on agricultural lands and degraded soils can enhance soil quality, including the available water holding capacity, cation exchange capacity, soil aggregation, and susceptibility to topsoil crusting and erosion, with positive effect on the capacity to store carbon. Research in Argentina, India, and the West African Sahel has found that crop yields can be increased by $20-70 \mathrm{~kg} / \mathrm{ha}$ for wheat, $10-50 \mathrm{~kg} / \mathrm{ha}$ for rice, and $30-300 \mathrm{~kg} / \mathrm{ha}$ for maize with every $1000 \mathrm{~kg} / \mathrm{ha}$ increase in soil organic carbon pool in the root zone. This has obvious benefits for food security in developing regions, and could also off-set fossil fuel emissions at the rate of $0.5 \mathrm{GtC} / \mathrm{year}$ through carbon sequestration in agricultural soils ${ }^{65}$. However, achieving such high increases in SOC requires high levels of water input, which is a major constraint in most drylands and implies potential externalities and opportunity costs that have not yet been adequately explored. 


\section{Investing in soil biodiversity and soil organic carbon}

Solutions for sustainably managing soil to conserve soil biodiversity and SOC are well-known and have been validated in different countries and geographic contexts. Nevertheless, many countries continue to prioritize less intensive land use practices, while sustainable approaches are side-lined from the mainstream. There are many challenges to mainstreaming SLM, including attitude barriers among decision-makers and investors and capacity constraints among land users.

SLM can be integrated into land-use planning ${ }^{66}$ and economic incentives for the implementation of SLM can be developed through sustainable business models, subsidies, or payments for ecosystem service. The latter often requires suitable knowledge, skills, technology and resources, including labour, energy and financial resources. Upfront investments costs can be high ${ }^{67}$ and the time-lag in realising benefits from investment can make such projects unattractive. Financial returns and other drivers of investment therefore need to be identified to foster adoption by landholders (farmers, tree growers, pastoralists).

The benefits of SLM practices are enjoyed by people other than landholders (Box 8) and these externalities can be used to foster incentives for investment, for example through payments for ecosystem services (PES). Attempts have been made to estimate the economic value of individual services provided by soils, SOC and soil biodiversity, including recent studies that have compiled these data into a more accessible format ${ }^{68}$. These rough estimates, however, vary considerably ranging from $\$ 2$ to $\$ 22,219 / \mathrm{ha} / \mathrm{y}^{69}$. While the estimates point to the need for further research, they nevertheless indicate that the total economic value of ecosystem services from SOC is likely to be substantial.

\section{Box 8. Incentives to invest in SLM are often other than financial}

A study among 500 farmers in West Africa found that the major drivers to invest included the presence of children (aged 6 to 14) in the household, land holding, land tenure, awareness and training on conservation measures, and access to alternative cash sources such as remittance ${ }^{70}$ Some of these factors could be targeted to upscale the adoption of sustainable practices in dryland areas of developing countries (or countries with transition economies). In many cases this will also involve better articulated local governance policies with respect to land tenure and management responsibilities ${ }^{71}$. SLM practices continue to be limited to a minority of innovative land-users and practitioners, highlighting that challenges to adoption of SLM are more complex than the simple cost of uptake of new technologies, including ecological, institutional, economic and sociocultural aspects ${ }^{72}$.

Returns on investment in land conservation or improvement can be expressed beyond monetary terms, through increased non-monetary benefits such as higher well-being, more secure livelihoods, cleaner water, reduced risks of disasters, recreation, habitat or nature value, spiritual and aesthetic experiences (Box 9). Many land users, for example, are motivated by spiritual or cultural values of land, and these services may not be well-measured in financial terms. Economic valuation alone may not capture what is at stake in a social and ecological agenda and there are risks in relying exclusively on market triggers to achieve sustainability ${ }^{73}$. Financial returns are not the only incentive for people to invest, and relying on such financial motives would assume that the value of nature and environment is only dependent of the function it has for human production and consumption.

\section{Box 9. Investing in SOC and agroforestry for food production - Africa}

The Kelka forest watershed, in the Mopti region of Mali, covers an area of over 300,000 ha, much of which has been degraded. Restoration of degraded land and adoption of agroforestry has the potential to generate 500 US\$ per hectare per year over a 25 year time horizon, indicating a benefit to cost ratio of 5.2:1 at a 10 per cent discount rate ${ }^{74}$. Research in Europe and China confirms that the tree component in agroforestry has positive effects on carbon sequestration, notably by the capacity of the deeper root systems to store carbon ${ }^{75}$. 
In the drylands, as in other ecosystems, higher levels of SOC are a key determinant of regulating and provisioning ecosystem services such as biodiversity, hydrological flows, food production, and carbon sequestration. Nurturing and investing to maintain quality and flows of these ecosystem services feeds back into maintaining high levels of SOC (Box 10). The challenge lies in mobilising financial resources for appropriate investment towards land multifunctionality.

\section{Box 10. Large scale landscape restoration in China}

In China, the 1994-2005 Loess Plateau projects mobilised USD 491 million in funding and curbed soil erosion on nearly 1 million ha of degraded land. The projects focused on halting the activities that led to degradation - in particular planting on steep slopes, tree-cutting, and free-range grazing of goats; introduced heavy equipment to build wider and sturdier terraces for grain cultivation, and encouraged farmers to plant trees and to allow marginal land to grow wild again. The projects sharply increased grain yields, restored the landscape, and lifted more than 2.5 million people out of poverty by tripling farmer incomes. Soil erosion was curbed on 900,000 ha of land, and soil losses were reduced by 60-100 Mt per year. Soil carbon storage also increased, mostly due to the restoration of forests and grassland. The project model has since been scaled up to cover large areas of the country, through China's US\$ 40 billion “Grain for Green” programme ${ }^{76}$.

Grasslands that dominate drylands are amongst the least protected biomes on earth. Protecting these areas through promoting sustainable pastoralism or other forms of grazing management can prevent increases in carbon emissions, while restoring grasslands in former croplands can increase carbon sequestration ${ }^{78}$. A cost-effective means of safeguarding soil biodiversity and soil organic carbon is to protect uncultivated land, such as natural grasslands and forests, from cultivation. Protected area coverage in drylands is close to the global mean, that is to say about $9 \%$ of the land is protected, falling short of the aspiration of Aichi Target 11 ("at least 17 per cent of terrestrial and inland water areas ... are conserved through ... systems of protected areas and other effective area-based conservation measures"79).

\section{Box 11. Funding external benefits from sustainable dryland agricultural management in Australia}

In Australia, the federal government has developed policy initiatives to encourage farmers to reduce emissions through their management practices. The main policy is a market-based mechanism to pay farmers from an Emissions Reduction Fund using methodologies specified under the Australian Carbon Farming Initiative. The Initiative allows farmers and land managers to earn carbon credits by storing carbon or reducing GHG emissions on their land. These credits can then be sold to people and businesses wishing to offset their emissions. The adoption of conservation agriculture practices in the dryland grain sector of Australia shows the potential to achieve emissions reductions in the order of three million tCO2e annually. The main driver of change in Australia seems to be the pursuit of agricultural productivity benefits rather than the environmental benefits of reducing GHG emissions, emphasising the need for sustainable land management policies and practices that provide financial returns to landholders. The main practices that are incentivised by the policy framework are conservation agriculture practices such as reduced tillage, retaining crop stubble, and planting of legumes, as detailed in the Carbon Farming Initiative Handbook ${ }^{77}$.

Many drylands offer a wide space for innovation in developing multiple value chains that reward multifunctionality. This has been achieved, for example, through marketing of sustainably harvested natural products, ecotourism, and certification of sustainably-produced commodities. Although each option may have limitations to its scope, they can provide important incentives for sustainable management combined with the opportunity for economic diversification and growth. Policy support for development of small and medium sized enterprises can be particularly relevant to fill this niche. 


\section{Box 12. The case of sustainable rangeland investments in Portugal}

Portugal introduced a soil carbon offset scheme based on dryland pasture improvement, allocating 8.5 million Euros to pay an estimated 400 participating farmers to improve around 42,000 ha of grasslands with the aim of sequestering 0.91 million tonnes of carbon dioxide equivalent. To achieve this, the farmers use a technique known as sown biodiverse permanent pastures rich in legumes, which increases carbon in degraded soils. The grassland areas generally have a low carbon stock and the technique has been shown to dramatically increase SOC in these degraded soils. Improvement of 42,000 ha would earn farmers about from EUR 150 to 200 per hectare of planted pastures ${ }^{80}$. Modalities for financing restoration and sustainable management of dryland soil organic carbon could be inspired by systems of payments for ecosystem services (PES) (see Box 12). A PES rationale could be used to justify international financial flows from external beneficiaries to those implementing and contributing to the investments in Sustainable Land Management, and hence maintaining and increasing SOC ${ }^{81}$. Enabling investments are also required in many countries, for example to secure land tenure so as to mitigate against inequitable outcomes, or to establish infrastructure that enables value chain development.

As the benefits of maintaining or strengthening dryland ecosystems services extend beyond direct users of the land, mechanisms of compensation by off-site beneficiaries to landholders may be needed to ensure the flow of benefits. Modalities are needed to ensure that "downstream" beneficiaries contribute to the benefits they enjoy, such as better ground water recharge and availability, reduced reservoir siltation, higher biodiversity, or higher carbon sequestration mitigating climate change. Indeed, some dryland ecosystem services also benefit society globally, and further innovation is needed to ensure global beneficiaries pay landholders to provide those services through the land management practices they follow ${ }^{83}$.

\section{Box 13. Sustainable rangeland investments in Jordan}

The investment packages proposed for sustainable rangeland management in Jordan, associated with those related to community protection of rangelands and associated local governance mechanisms have high potential to create local and societal ecosystem benefits, and to contribute globally to biodiversity conservation, climate change mitigation and other goals. The 20 million USD/year contribution, as engendered by the proposed investment packages in $30 \%$ of Jordan's rangelands, could provide a basis for attracting the capital and financial flows required. Indeed, on this basis proposals have been developed for a payment for ecosystem services scheme that could comprise two ecosystem service payments: a green pasture credit in the form of a subsidy to herder cooperatives responsible for sustainable rangeland management in designated areas and a green water credit to the same cooperatives for enhancing ground water recharge. A global system of Payment for Ecosystem Services could provide the necessary platform, while investments in ecotourism and renewable energy could provide the vehicle, through taxation and licensing, for country-level PES modalities. Both PES modalities could provide the financing flows (national and international) needed to invest in higher biomass production and biodiversity, soil conservation, improved water flows, carbon sequestration, and in required local governance structures. The Jordanian Government is considering a range of enabling measures, including the establishment of a Rangeland Ecological Economic Zone, Verified Conservation Areas, and a Rangeland Ecosystem Management Fund ${ }^{82}$. 


\section{Policy options to conserve soil biodiversity and soil organic carbon}

This Technical Brief highlights how Soil Organic Carbon and Soil Biodiversity provide the foundation for terrestrial ecosystem services. They are among the principal determinants of food production, water supply, above-ground biodiversity and climate regulation, and they play a major role in rural livelihoods and disaster risk reduction. Soil biodiversity and soil organic carbon are both natural resources and public goods, and government has an important role to play in ensuring that land is managed for the welfare of society.

Drylands offer greater possibilities for carbon sequestration and climate change mitigation than is widely acknowledged. They cover a large part of the earth and a significant proportion of the land has lost SOC through land degradation processes. Dryland restoration and rehabilitation offer globally important opportunities for carbon sequestration. However, conventional approaches to restoration often need to be adapted to the local conditions of drylands, while both policies and investments need to be supported by improved data on existing and potential SOC levels.

Government strategies are needed to guide investments in drylands by local land users, private companies and other stakeholders, in order to fulfil their public responsibility for protecting and promoting the multifunctionality of land. Investments in soil biodiversity and soil organic carbon in the drylands can yield significant returns due both to the number and value of the co-benefits, and the large surface area of land involved. However, investments need to be tailored towards delivering multi-functionality at scale rather than maximising single goods or services.

A number of measures can be adopted to create conditions that enable better investment in Soil Organic Carbon and Soil Biodiversity. Six complementary options stand out and are discussed in this section:

1. Evaluate land management against the sustainable delivery of multiple goods and services;

2. Build on policies and legislation to enable scaling-up of sustainable land management and landscape restoration or rehabilitation;

3. Enhance local governance mechanisms that support land users in sustainable land management practices;

4. Strengthen land information to support landscape-scale planning and monitoring;

5. Establish effective extension services that support land users to adopt sustainable land management practices;

6. Create enabling conditions for private investment in sustainable land management.

\section{- Evaluate land management against the sustainable delivery of multiple goods and services}

Further efforts are required to strengthen the economic case for sustainable management of soil organic carbon and soil biodiversity through providing evidence of the multiple economic benefits, and by monitoring the performance of land users against multiple ecosystem services. The technologies exist and have been tested in many different contexts to demonstrate the benefits of sustainable land management to land users and wider society. Economic valuations can also guide policy, by demonstrating the cost-benefit ratio of adopting SLM and identifying areas where additional incentives, such as payments for ecosystem services may be required to support the transition to more sustainable practices. In some cases further evidence is needed of the extent to which soil organic carbon and soil biodiversity contribute to above-ground biomass, agricultural productivity, water cycling, and climate change mitigation.

\section{- Build on policies and legislation to enable scaling-up of sustainable land management and landscape restoration or rehabilitation}

Policy and legislation is needed to shift sustainable land management from peripheral projects to core investments in agriculture and other land use. This could take the form of explicit support for certain types of land management (e.g. agroforestry, conservation agriculture, range management), or regulation to deliver against key indicators of sustainability, such as soil organic carbon. Incentives may also be needed where 
investments in sustainable land management are beyond the financial or organizational means of local land users. In this context, it is important to understand the value of established risk-management strategies of land users; reluctance to abandon tried-and-tested strategies should not be mistaken for ignorance. Achieving multifunctional land use also requires institutional arrangements for cross-sectoral coordination or collaboration in land management, and for local governance modalities for natural resource management. Overall this requires promoting sustainable land management, and prioritising national targets for Land Degradation Neutrality in national policy agendas.

\section{- Enhance local governance mechanisms that support land users in sustainable land management practices}

Government policy support is also needed to strengthen local natural resource governance and tenure security. Secure land tenure and effective local governance over natural resources are vital for achieving sustainable land management and to maintain or increase soil organic carbon and soil biodiversity. The rights of men and women and indigenous peoples to access and to manage land must be upheld. This may involve the (re-)establishment of local institutions and rules that facilitate application of local knowledge; for example, local rules over cutting of trees, access to water, or grazing of seasonal pastures. Respect for local knowledge and institutions, building consensus and ensuring equity through participatory approaches, policy, legislative and institutional support, and secure resource and land tenure are all part of local governance as a set of systems that control and mediate decision making by local actors, in consultation with concerned external stakeholders, with regard to land resource development and management.

\section{- Strengthen land information to support landscape-scale planning and monitoring}

Ensure that key biophysical and socio-economic data on land is available for decision-makers from the local to the national level. This includes information on land use, land potential, land tenure, trends in land use change, land value, potential for soil and above-ground carbon sequestration, and the status of land degradation. These data need to be maintained up-to-date and should be accessible to all users. In most countries, greater investment is required in monitoring land degradation, including the indicators agreed by the Parties of the UNCCD to track progress made in achieving Land Degradation Neutrality: trends in land cover, trends in land productivity or functioning of the land, and trends in carbon stocks above and below ground.

\section{- Establish effective services that support land users to adopt sustainable land management practices}

Extension services need to be designed to advance sustainable land management, or key elements of sustainability, as their core business. Governments need to make decisions over how sustainable land management will be promoted, while farmers need training on new approaches, for example in agroforestry or conservation agriculture. In many cases this will require major professional updating of extension staff combined with investment in vocational training and higher education curricula to overcome decades of promoting unsustainable land management systems. Where the adoption of sustainable land management exposes land users to new risks, or where the required investments are beyond their financial or organizational capacity, incentives and risk-mitigation measures may be required. These incentives will frequently be justified by the high value and diversity of the societal benefits reaped, from local to global level.

\section{- Create enabling conditions for private investment in sustainable land management}

Sustainable land management frequently requires changes to agricultural practices and inputs, and in some cases could also influence the type of agricultural outputs. This has significant implications for the private sector. Private business has a major role to play in developing innovative products and services and new markets that support SLM practices. For example, reducing soil tillage may require changes in fertiliser and herbicide regimes and may require adapted farm machinery. Greater attention needs to be placed on diversifying markets to reflect the wider range of values that are provided by healthy land. This includes markets for ecosystem services, and could also include certifying high-value niche products such as medical herbs and ecological livestock products from sustainable agricultural systems or landscapes. 


\section{References}

Adhikari K. and Hartemink A.E., 2016. Linking soils to ecosystem services-A global review. Geoderma, 262, 101-111. https://doi.org/10.1016/j.geoderma.2015.08.009

Aerni P., 2016. The sustainable provision of environmental services. From regulation to innovation. Springer: Switzerland. https://doi.org/10.1007/978-3-319-19345-8

Álvaro-Fuentes J., López M.V., Cantero-Martinez C. and Arrúe J.L., 2007. Tillage Effects on Soil Organic Carbon Fractions in Mediterranean Dryland Agroecosystems. Soil Science Society of America Journal Abstract - SOIL and WATER MANAGEMENT and CONSERVATION; Vol. 72 No. 2, p. 541-547

Amundson R., Berhe A.A., Hopmans J.W., Olson C., Sztein A.E. and Sparks D.L., 2015. Soil and human security in the 21st century. Science, 348, 1261071. https://doi.org/10.1126/science.1261071

Arriagada R. and Perrings C., 2009. Making Payments for Ecosystem Services Work. Policy Brief, UNEP: Nairobi. 32 pages. Available at: http://bioecon-network.org/pages/UNEP_publications/02\%20PES.pdf

Australian Government, 2012. The Carbon Farming Initiative Handbook, Canberra, Australia, Australian Department of Climate Change and Energy Efficiency.

Bai Z.G., Dent D.L., Olsson L. and Schaepman M.E., 2008. Proxy global assessment of land degradation. Soil use and management, 24, 223-234. https://doi.org/10.1111/j.1475-2743.2008.00169.x

Banwart S., Black H., Cai Z., Gicheru P., Joosten H., Victoria R., Milne E., Noellemeyer E., Pascual U. and Nziguheba G., 2014. Benefits of soil carbon: report on the outcomes of an international scientific committee on problems of the environment rapid assessment workshop. Carbon Management, 5, 185-192. https://doi.org/10.1080/1758 3004.2014 .913380

Bastin J-F., Berrahmouni N., Grainger A., Maniatis D., Mollicone D., Moore R., Patriarca C., Picard N., Sparrow B. and Abraham E. M., 2017. The extent of forest in dryland biomes. Science, 356, 635-638. https://doi.org/10.1126/ science.aam6527

Batjes N., 2016. Harmonized soil property values for broad-scale modelling (WISE30sec) with estimates of global soil carbon stocks. Geoderma, 269, 61-68. https://doi.org/10.1016/j.geoderma.2016.01.034

Batjes N.H., 2004. Estimation of soil carbon gains upon improved management within croplands and grasslands of Africa. Environment, Development and Sustainability 6: 133-143. https://doi.org/10.1023/B:ENVI.0000003633.14591.fd

Baveye P.C., Baveye J. and Gowdy J., 2016. Soil "ecosystem" services and natural capital: Critical appraisal of research on uncertain ground. Frontiers in Environmental Science, 4, 41. https://doi.org/10.3389/fenvs.2016.00041

Beare M., Mcneill S., Curtin D., Parfitt R., Jones H., Dodd M, and Sharp J., 2014. Estimating the organic carbon stabilisation capacity and saturation deficit of soils: a New Zealand case study. Biogeochemistry, 120, 71-87. https://doi. org/10.1007/s10533-014-9982-1

Belnap J. and Lange O.L., 2003. Biological Soil Crusts: Structure, Function, and Management. Ecological Studies, Volume 150. https://doi.org/10.1007/978-3-642-56475-8

Bernoux M. and Chevallier T., 2014. Carbon in dryland soils: multiple essential functions. In: INTERNATIONAL, C. A. (ed.) Les dossiers thematiques du CSFD. France.

Bishop J. and Hill C. (eds.), 2014. Global Biodiversity Finance: The Case for International Payments for Ecosystem Services. Edward Elgar, Cheltenham. https://doi.org/10.4337/9781782546955

Blair G.J., Lefroy R.D. and Lisle L., 1995. Soil carbon fractions based on their degree of oxidation, and the development of a carbon management index for agricultural systems. Crop and Pasture Science, 46, 1459-1466.

Bonachela J.A., Pringle R.M., Sheffer E., Coverdale T.C., Guyton J.A., Caylor K.K., Levin S.A. and Tarnita C.E., 2015. Termite mounds can increase the robustness of dryland ecosystems to climatic change. Science, Vol. 347 , No. 6222, 06.02.2015, p. 651-655.

Booker K., Huntsinger L., Bartolome J.W., Sayre N.F. and Stewart W., 2013. What can ecological science tell us about opportunities for carbon sequestration on arid rangelands in the United States? Global Environmental Change Vol 23 (1), February 2013, Pages 240-251. https://doi.org/10.1016/j.gloenvcha.2012.10.001

Boucher D. and Ferretti-Gallon K., 2015. Halfway There? What the Land Sector Can Contribute to Closing the Emissions Gap. Union of Concerned Scientists.

Brady M.V., Hedlund K., Cong R-G., Hemerik L., Hotes S., Machado S., Mattsson L., Schulz E. and Thomsen I.K., 2015. Valuing supporting soil ecosystem services in agriculture: a Natural Capital Approach. Agronomy Journal, 107, 1809-1821. https://doi.org/10.2134/agronj14.0597

Brady N. and Weil R., 1999. The nature and properties of soil 12th ed. Prentice-Hall Inc. Upper Saddle River, New Jersey. 
Cardinael R., Chevallier T., Cambou A., Beral C., Barthes B.G., Dupraz C., Durand C., Kouakoua E. and Chenu C., 2016. Increase of soil organic carbon stock under agroforestry: a survey of different sites in France. Presentation at Third European Agroforestry Conference, 23-25 May 2016, Montpellier

Comerford N.B., Franzluebbers A.J., Stromberger M.E., Morris L., Markewitz D. and Moore R., 2013. Assessment and evaluation of soil ecosystem services. Soil Horizons, 54.

Conant R.T., Six J. and Paustian K., 2003. Land use effects on soil carbon fractions in the southeastern United States. Management-intensive versus extensive grazing. Biol Fertil Soils (2003) 38:386-392

Cooper P.J., Cappiello S., Vermeulen S., Campbell B.M., Zougmoré R.B. and Kinyangi J., 2013. Large-scale implementation of adaptation and mitigation actions in agriculture.

Dang Y., Ren W., Tao B., Chen G., Lu C., et al., 2014. Climate and Land Use Controls on Soil Organic Carbon in the Loess Plateau Region of China. PLOS ONE 9(5): e95548. https://doi.org/10.1371/journal.pone.0095548

Davies J., Poulsen L., Schulte-Herbrüggen B., Mackinnon K., Crawhall N., Henwood W.D., Dudley N., Smith J. and Gudka M., 2012. Conserving Dryland Biodiversity. IUCN, Nairobi, xii +84p

Davies J., Niamir-Fuller M., Kerven C. and Bauer K., 2010. Extensive Livestock Production in Transition: The Future of Sustainable Pastoralism. In: Steinfeld et al. (eds.), Livestock in a Changing Landscape, Volume 1: Drivers, consequences and responses. Island Press.

Davies J., Ogali C., Laban P., Metternicht G., 2015. Homing in on the Range: Enabling Investments for Sustainable Land Management. Technical Brief 29/01/2015. IUCN Global Drylands Initiative and the IUCN Commission on Ecosystem Management

Diaz-Zorita M., Duarte G.A. and Grove J.H., 2002. A review of non-till systems and soil management for sustainable crop production in the subhumid and semiarid Pampas of Argentina. Soil and Tillage Research 65, 1-18. https://doi. org/10.1016/S0167-1987(01)00274-4

Dumanski J., Peiretti R., Benetis J., McGarry D. and Pieri C., 2006. The paradigm of conservation tillage. Proc. World Assoc. Soil and Water Conserv., P1: 58-64.

ELD INITIATIVE, 2015. The value of land: Prosperous lands and positive rewards through sustainable land management. The Economics of Land Degradation, Bonn, Germany.

Emerson W., 1995. Water-retention, organic-C and soil texture. Soil Research, 33, 241-251. https://doi.org/10.1071/ SR9950241

FAO, 2007. State of the World's forests 2007. Food and Agricultural Organization of the United Nations, Rome.

FAO, 2009. How to Feed the World in 2050. Issues Brief for the High-Level Expert Forum, Rome 12-13 October 2009. Food and Agricultural Organisation of the United Nations, Rome. http://www.fao.org/wsfs/forum2050/wsfsbackground-documents/issues-briefs/en/

FAO, 2017. Soil Organic Carbon: the hidden potential. Food and Agriculture Organisation of the United Nations, Rome.

Farage P., Pretty J. and Ball A., 2003. Biophysical Aspects of Carbon Sequestration in Drylands. University of Essex.

Ferrenberg S., Reed S.C. and Belnap J., 2015. Climate change and physical disturbance cause similar community shifts in biological soil crusts. Proceedings of the National Academy of Sciences, USA 112: 12116-12121

Ferrenberg S., Tucker C. and Reed S., 2017. Biological soil crusts: Diminutive communities of potential global importance. Frontiers in Ecology and the Environment 15(3). https://doi.org/10.1002/fee.1469

Gifford R.M., Cheney N.P., Nobel J.C., Russell J.S., Wellington A.B. and Zammit C., 1992. Australian Land Use, primary production of vegetation and carbon pools in relation to atmospheric carbon dioxide levels. Bureau of Rural Resources Proceeding 14, 151-187.

Gougoulias C., Clark J.M. and Shaw L.J., 2014. The role of soil microbes in the global carbon cycle: tracking the belowground microbial processing of plant-derived carbon for manipulating carbon dynamics in agricultural systems. Journal of the Science of Food and Agriculture, 94, 2362-2371. https://doi.org/10.1002/jsfa.6577

Havlicek E. and Mitchell E.A., 2014. Soils Supporting Biodiversity. Interactions in Soil: Promoting Plant Growth. Springer. INTERGOVERNMENTAL TECHNICAL PANEL ON SOIL, 2015. Status of the World's Soil Resources. Rome, Italy.

Jenkinson D.S., Harris H.C., Ryan J., Mcneil A.M., Pilbeam C.J. and Coleman K., 1999. Organic matter turnover in calcareous soil from Syria under a two-course cereal rotation. Soil Biology and Biochemistry 31, 687-693. https://doi.org/10.1016/S0038-0717(98)00157-6

Jónsson J.Ö.G. and Davíđsdóttir B., 2016. Classification and valuation of soil ecosystem services. Agricultural Systems, 145, 24-38. https://doi.org/10.1016/j.agsy.2016.02.010

Kibblewhite M., Chambers B. and Goulding K., 2016. How good is the evidence to support investment in soil protection? Soil Use and Management, 32, 172-182. https://doi.org/10.1111/sum.12236 
Kirk G. and Bellamy P., 2010. Analysis of changes in organic carbon in mineral soils across England and Wales using a simple single-pool model. European journal of soil science, 61, 406-411. https://doi.org/10.1111/j.13652389.2010.01242.x

Koch A., Mcbratney A., Adams M., Field D., Hill R., Crawford J., Minasny B., Lal R., Abbott L. and O'Donnell A., 2013. Soil security: solving the global soil crisis. Global Policy, 4, 434-441. https://doi.org/10.1111/1758-5899.12096

Köchy, M., Hiederer R. and Freibauer A., 2015. Global distribution of soil organic carbon-Part 1: Masses and frequency distributions of SOC stocks for the tropics, permafrost regions, wetlands, and the world. Soil, 1, 351-365. https://doi.org/10.5194/soil-1-351-2015

Kpadonou R.A.B., Owiyo T., Barbier B., Denton F., Rutabingwa F. and Kiema A., 2017. Advancing climate-smart-agriculture in developing drylands: Joint analysis of the adoption of multiple on-farm soil and water conservation technologies in West African Sahel. Land Use Policy, 61, 196-207. https://doi.org/10.1016/j.landusepol.2016.10.050

Kumar P., 2010. The economics of ecosystems and biodiversity: ecological and economic foundations, UNEP/Earthprint.

Laban/IUCN-MoA Jordan, 2015. Sustainably Investing in the Jordan Rangelands; a study on rangeland investment options commissioned by IUCN and the Jordan MoA. IUCN ROWA, Amman

Lal R., 2006. Enhancing crop yields in the developing countries through restoration of the soil organic carbon pool in agricultural lands. Land Degradation and Development, 17, 197-209. https://doi.org/10.1002/ldr.696

Lal R., 2008. Soil health and carbon management. Food and Energy Security. Volume 5, Issue 4

Li J., Luo J., Shi Y., Houlbrooke D., Wang L., Lindsey S. and Li Y., 2015. Nitrogen gaseous emissions from farm effluent application to pastures and mitigation measures to reduce the emissions: a review, New Zealand Journal of Agricultural Research. https://doi.org/10.1080/00288233.2015.1028651

Martin-Piera F. and Lobo J.M., 1995. Diversity and ecological role of dung beetles in Iberian grassland biomes. In: Farming on the edge: the nature of traditional farmland in Europe, ed. by. DJ. McCracken, EM. Bignal and SE. Wenlock, 147-153. Peterborough, Joint Nature. Conservation Committee.

McBratney A., Field D.J. and Koch A., 2014. The dimensions of soil security. Geoderma, 213, 203-213. https://doi. org/10.1016/j.geoderma.2013.08.013

McGahey D., Davies J., Hagelberg N. and Ouedraogo R., 2014. Pastoralism and the Green Economy - a natural nexus? Nairobi: IUCN and UNEP. $x+58 p$

Metternicht G., 2018. Land Use and Spatial Planning Enabling Sustainable Management of Land Resources. Springer Briefs in Earth Sciences. 116 pages. Springer Nature: Switzerland.

Milne E., Banwart S.A., Noellemeyer E., Abson D.J., Ballabio C., Bampa F., Bationo A., Batjes N.H., Bernoux M. and Bhattacharyya T., 2015. Soil carbon, multiple benefits. Environmental Development, 13, 33-38. https://doi. org/10.1016/j.envdev.2014.11.005

Nair P.K.R., Kumar B.M. and Nair V., 2009. Agroforestry as a strategy for carbon sequestration. Journal of Plant Nutrition and Soil Science 172(1):10 - 23. https://doi.org/10.1002/jpln.200800030

Nellemann C., 2009. The environmental food crisis: the environment's role in averting future food crises: a UNEP rapid response assessment, UNEP/Earthprint.

NEW CLIMATE ECONOMY, 2014. Better growth, better climate. The New Climate Economy Report, The Global Commission on the Economy and Climate.

Orgiazzi A., Bardgett R.D., Barrios E., Behan-Pelletier V., Briones M.J., Chotte J-L., De Deyn G.B., Eggleton P., Fierer N. and Fraser T., 2016. Global soil biodiversity atlas. Publications Office of the European Union.

O’Rourke S.M., Angers D.A., Holden N.M. and McBratney A.B., 2015. Soil organic carbon across scales. Global change biology, 21, 3561-3574. https://doi.org/10.1111/gcb.12959

Ospina C., 2017. Climate and economic benefits of agroforestry systems. The Climate Institute, Washington

Petersen E. and Hoyle F., 2016. Estimating the economic value of soil organic carbon for grains cropping systems in Western Australia. Soil Research, 54, 383-396. https://doi.org/10.1071/SR15101

Pribyl D.W., 2010. A critical review of the conventional SOC to SOM conversion factor. Geoderma, 156, 75-83. https://doi. org/10.1016/j.geoderma.2010.02.003

Rochecouste J-F., Dargusch P., Cameron D. and Smith C., 2015. An analysis of the socio-economic factors influencing the adoption of conservation agriculture as a climate change mitigation activity in Australian dryland grain production. Agricultural Systems, 135, 20-30. https://doi.org/10.1016/j.agsy.2014.12.002

Rockstrom J., Steffen W., Noone K., Persson Å., Stuart III Chapin F., Lambin E., et al., 2009. Planetary Boundaries: Exploring the Safe Operating Space for Humanity. Resilience Alliance. Ecology and Society 14(2): 32. [online] URL: http://www.ecologyandsociety.org/vol14/iss2/art32/ 
Safriel U., Adeel Z., Niemeijer D., Puigdefabregas J., White R., Lal R., Winslow M., Ziedler J., Prince S., Archner E. and King C., 2005. Dryland systems. In: Hassan, R Scholes, R.J., Ash, N. (Eds.), Ecosystems Human Well-Being. Findings of the Conditions Trends Working Group of the Millennium Ecosystem Assessment, vol. 1. Island Press, Washington D.C., U.S.A, pp. 623-662.).

Scharlemann J.P., Tanner E.V., Hiederer R. and Kapos V., 2014. Global soil carbon: understanding and managing the largest terrestrial carbon pool. Carbon Management, 5, 81-91. https://doi.org/10.4155/cmt.13.77

Sidibe Y., Myint M. and Westerberg V., 2014. An economic valuation of agroforestry and land restoration in the Kelka Forest, Mali. Assessing the socio-economic and environmental dimensions of land degradation. Report for the Economics of Land Degradation Initiative. Nairobi, Kenya.

Silveira M.C.T., da Silva S.C., De Souza Junior S.J., Martins Barbero L., Santos Rodrigues C., Limão V.A., da Silva Pena K. and Do Nascimento Junior D., 2013. Herbage accumulation and grazing losses on Mulato grass subjected to strategies of Márcia Cristina Teixeira da Silveira. Scientia Agricola 704:242-249. https://doi.org/10.1590/ S0103-90162013000400004

Six J., Conant R., Paul E.A. and Paustian K., 2002. Stabilization mechanisms of soil organic matter: implications for C-saturation of soils. Plant and soil, 241, 155-176.

Smith P., 2005. An overview of the permanence of soil organic carbon stocks: influence of direct human-induced, indirect and natural effects. European Journal of Soil Science, October 2005, 56, 673-680

Smith P., 2014. Do grasslands act as a perpetual sink for carbon? Global change biology, 20, 2708-2711. https://doi. org/10.1111/gcb.12561

Smith P., Haberl H., Popp A., Erb K.H., Lauk C., Harper R., Tubiello F.N., Siqueira Pinto A., Jafari M. and Sohi S., 2013. How much land-based greenhouse gas mitigation can be achieved without compromising food security and environmental goals? Global Change Biology, 19, 2285-2302. https://doi.org/10.1111/gcb.12160

Sudgen A., Stone R. and Ash C., 2004. Soils-The Final Frontier. Science, 304, 1613.

Teague W.R., Dowhowera S.L., Baker S.A., Haile N, DELAUNE PB and CONOVER DM, 2011. Grazing management impacts on vegetation, soil biota and soil chemical, physical and hydrological properties in tall grass prairie. Agriculture, Ecosystems and Environment, Vol 141, Issues 3-4, Pages 310-322. https://doi.org/10.1016/j. agee.2011.03.009

UNCCD SPI, 2017 Policy Brief No. 3: Sustainable Land Management Solutions. http://www2.unccd.int/sites/default/files/ documents/2017-09/Policy_brief_ENG.pdf

UNESCO, 2012. The United Nations World Water Development Report 4: Managing Water under Uncertainty and Risk. Paris, UNESCO.

UNEP, 2011. Towards a Green Economy: Pathways to Sustainable Development and Poverty Eradication. United Nations Environment Programme, Nairobi.

van Der Putten W.H., Anderson J., Bardgett R., Behan-Pelletier V., Bignell D., Brown G., Brown V., Brussaard L., Hunt H. and Ineson P., 2004. The sustainable delivery of goods and services provided by soil biota. Sustaining biodiversity and ecosystem services in soils and sediments: $15-43$.

van Der Wal A. and De Boer W., 2017. Dinner in the dark: Illuminating drivers of soil organic matter decomposition. Soil Biology and Biochemistry, 105, 45-48. https://doi.org/10.1016/j.soilbio.2016.11.006

Vignola R., Harvey C.A., Bautista-Solis P., Avelino J., Rapidel B., Donatti C. and Martinez R., 2015. Ecosystem-based adaptation for smallholder farmers: Definitions, opportunities and constraints, In Agriculture, Ecosystems and Environment, Volume 211, 2015, Pages 126-132, ISSN 0167-8809

Wang S., Wilkes A., Zhang Z., Chang X., Lang R., Wang Y. and Niu H., 2011. Management and land use change effects on soil carbon in northern China's grasslands: a synthesis, Agriculture, Ecosystems and Environment 142 (2011) 329- 340. https://doi.org/10.1016/j.agee.2011.06.002

Watson L., 2010. Portugal gives green light to pasture carbon farming as a recognised offset. Australian Farm Journal, 44-47.

Weber J-L., 2007. Accounting for soil in the SEEA. European Environment Agency, Rome.

Weissert L., Salmond J. and Schwendenmann L., 2016. Variability of soil organic carbon stocks and soil CO2 efflux across urban land use and soil cover types. Geoderma, 271, 80-90. https://doi.org/10.1016/j.geoderma.2016.02.014

Zomer R.J., Trabucco A., Coe R. and Place F., 2009. Trees on farm: analysis of global extent and geographical patterns of agroforestry. ICRAF Working Paper. Nairobi: World Agroforestry Centre (ICRAF). 


\section{Endnotes}

1. Sudgen et al., 2004, Weber, 2007; Jónsson and Davíðsdóttir, 2016; Brady and Weil, 1999

2. Orgiazzi et al., 2016

3. Ferrenberg et al., 2015; Ferrenberg et al., 2017

4. Bernoux and Chevallier, 2014; Pribyl, 2010; FAO, 2017; Kibblewhite et al., 2016

5. Bonachela et al., 2015; Marint-Piera and Lobo, 1995; Orgiazzi et al., 2016.

6. Belnap and Lange, 2003

7. Brady and Weil, 1999

8. Van der Putten et al., 2004

9. Amundson et al., 2015

10. Emerson, 1995

11. Havlicek and Mitchell, 2014

12. Bernoux and Chevallier, 2014

13. Brady et al., 2015

14. Available from www.iucn.org/drylands:

- Land Degradation Neutrality: implications and opportunities for conservation. https://www.iucn.org/ sites/dev/files/content/documents/tech_brief_land_degradation_neutrality_revised_2017_2.pdf

- Homing in on the Range: Enabling Investments for Sustainable Land Management. http://cmsdata. iucn.org/downloads/technical_brief__investing_in_slm_2.pdf

15. Banwart et al., 2014; Milne et al., 2015; Baveye et al., 2016; van der Wal and de Boer, 2017; Bernoux and Chevallier, 2014; FAO, 2017, Havlicek and Mitchell, 2014; Brady et al., 2015

16. ELD Initiative, 2015

17. van der Putten et al., 2004

18. Boucher and Ferretti-Gallon, 2015

19. Bai et al., 2008

20. FAO, 2009; UNESCO, 2012; Nellemann, 2009

21. New Climate Economy, 2014

22. ELD Initiative, 2015

23. Scharlemann et al., 2014; Batjes, 2016

24. Weissert et al., 2016; Batjes, 2016

25. Gougoulias et al., 2014; Köchy et al., 2015

26. O'Rourke et al., 2015

27. Blair et al., 1995; FAO, 2017

28. Petersen and Hoyle, 2016

29. Kibblewhite et al., 2016; Kirk and Bellamy, 2010; Smith, 2014

30. Davies et al., 2012

31. Bastin et al., 2017

32. http://www.unccd.int/Lists/SiteDocumentLibrary/WDCD/DLDD\%20Facts.pdf

33. http://www.fao.org/fileadmin/user_upload/newsroom/docs/i0372e01.pdf

34. Davies et al, 2012

35. Safriel et al, 2005

36. Davies et al., 2015

37. Safriel et al, 2005

38. Bernoux and Chevallier, 2014; Lal, 2008

39. Gifford et al., 1992

40. Smith 2005

41. Six et al., 2002; Beare et al., 2014

42. Álvaro-Fuentes et al, 2007

43. Laban/IUCN-MoA Jordan, 2015

44. Diaz-Zorita et al., 2002; Jenkinson et al., 1999.

45. Farage et al., 2003

46. FAO, 2007

47. Batjes 2004

48. FAO, 2009

49. UNEP, 2011; Intergovernmental Technical Panel on Soil, 2015; FAO, 2017

50. McBratney et al.,2014

51. McBratney et al., 2014; Koch et al., 2013; Bernoux and Chevallier, 2014

52. Bernoux and Chevallier, 2014

53. FAO, 2017

54. Dumanski et al., 2006

55. Davies et al., 2010; McGahey et al., 2014

56. http://www.fao.org/forestry/agroforestry/80338/en/

57. Vignola et al, 2015

58. Laban/IUCN-MoA Jordan, 2015

59. Conant et al. 2003

60. Wang et al. 2011; Silveira et al. 2013; Smith et al. 2013 
61. Teague et al. 2011

62. McGahey et al. 2014

63. Li et al. 2013

64. Nair et al., 2009; Zomer et al., 2009

65. Lal, 2006

66. Metternicht, 2018

67. Aerni, P. 2016

68. Jónsson and Davíðsdóttir, 2016; Adhikari and Hartemink, 2016; Comerford et al., 2013; Kumar, 2010; Banwart et al., 2014; Baveye et al., 2016; Milne et al., 2015; Brady et al., 2015

69. A summary of the economic value estimated in the literature for a range of different ecosystem services provided by soil can be found in Cameron et al., 2017

70. Kpadonou et al., 2017

71. Davies et al., 2015; Laban/IUCN-MoA Jordan, 2015

72. UNCCD SPI, 2017

73. Rowarth, 2017; Rockstrom, 2009

74. Sidibe et al., 2014

75. Cardinael, et al, 2016; Ospina, 2017

76. Dang et al., 2014; Cooper et al., 2013; New Climate Economy, 2014

77. Rochecouste et al., 2015; Australian Government, 2012

78. Booker et al 2013

79. https://www.cbd.int/sp/targets/rationale/target-11/

80. Watson, 2010

81. Bishop and Hill, 2014; Laban/IUCN-MoA Jordan, 2015

82. Laban/IUCN-MoA Jordan, 2015

83. Arriagada and Perrings, 2009 




\section{IUCN}

\section{INTERNATIONAL UNION FOR CONSERVATION OF NATURE}

Global Drylands Initiative

Mukoma Road (off Magadi Rd)

P. O. Box 68200 - 00200

NAIROBI, Kenya

Tel: +254 $202493561 / 65$

$+254724256804$

+254734768770

www.iucn.org

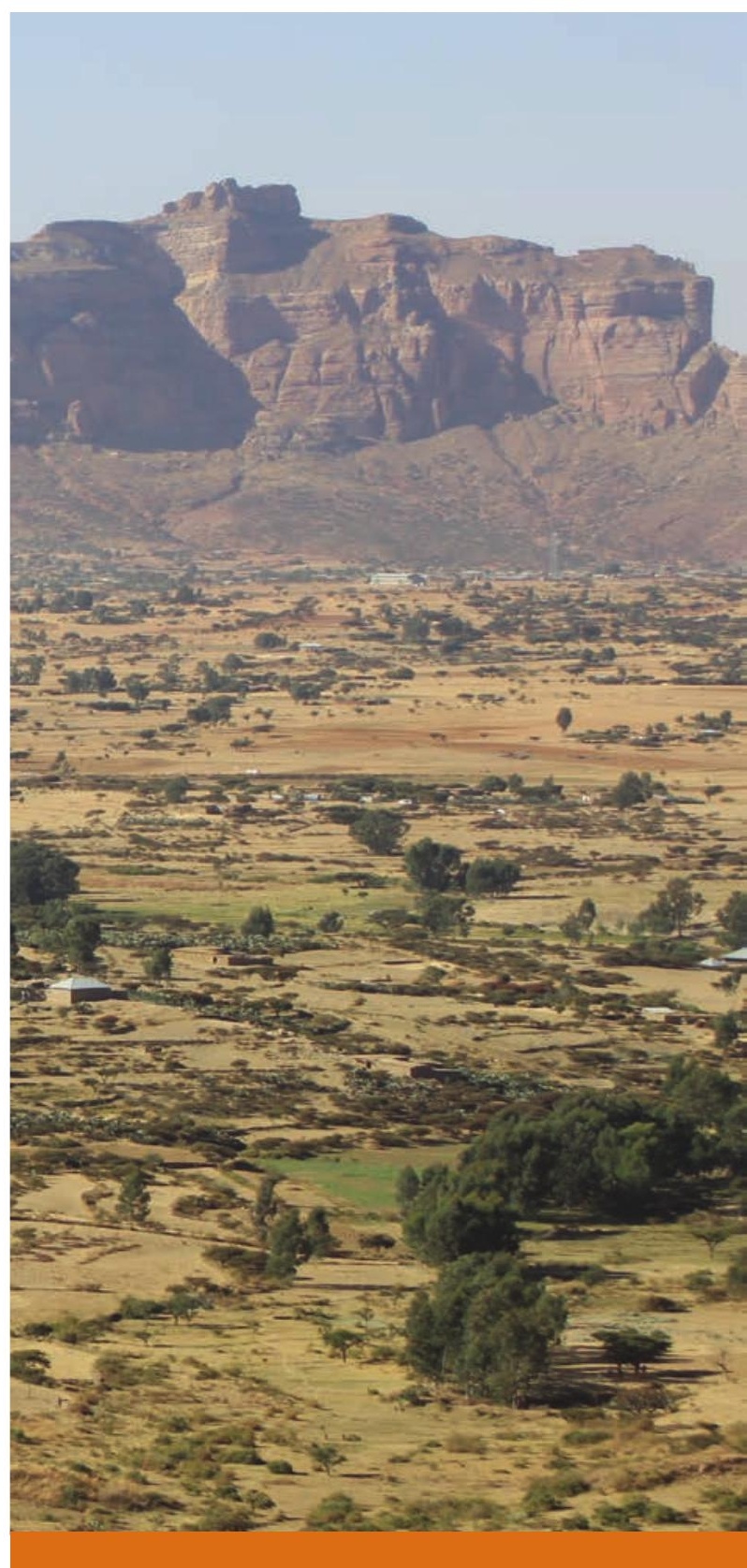

